\title{
0 dever de sigilo do médico: um roteiro da lei portuguesa ${ }^{1}$
}

André Gonçalo Dias Pereira²

"O que, no exercício ou fora do exercício e no comércio da vida, eu vir ou ouvir, que não seja necessário revelar, conservarei como segredo.”

Juramento de Hipócrates ${ }^{3}$

"Respeitarei os segredos que me foram confiados, mesmo após a morte do paciente." ${ }^{4}$

Declaração de Genebra da Associação Médica Mundial ${ }^{5}$

1 Este texto corresponde com pequenas alterações à conferência apresentada no Centro de Estudos Jurídicos e Judiciários da Região Administrativa Especial de Macau, República Popular da China, a convite do seu Ex.mo Director, Senhor Dr. Manuel Trigo, no dia 21 de Julho de 2008.

2 Assistente da Faculdade de Direito da Universidade de Coimbra. Pós-graduado em Direito Civil e em Direito da Medicina pela Universidade de Coimbra; Mestre e Doutorando em Ciências Jurídico-civilísticas pela Universidade de Coimbra. Secretário Científico do Centro de Direito Biomédico. Email: andreper@fd.uc.pt

3 Apud Maria Helena Diniz, O estado atual do Biodireito, 2. ${ }^{\text {a }}$ edição, São Paulo, Saraiva, 2002, p. 565 .

Na versão em inglês: "Whatever, in connection with my Professional practice, or not in connection with it, I see or hear in the life of men, which ought not be spoken of abroad, I will not divulge, as reckoning that all such should be kept secret." The Hippocratic Oath, Apud Margaret Brazier, Medicine, Patient and the Law, Penguin Books, p. 46.

4 Na versão inglesa: "I WILL RESPECT the secrets that are confided in me, even after the patient has died."

5 A Declaração de Genebra foi adoptada pela 2. ${ }^{a}$ Assembleia Geral da Associação Médica Mundial, em Genebra, Suíça, em Setembro de 1948 e alterada pela 22. ${ }^{a}$ Assembleia Geral da AMM em Sidney, Austrália, em Agosto de 1968, pela 35. ${ }^{a}$ Assembleia Geral da AMM, em Veneza, Itália, em Outubro de 1983 e pela 46. Assembleia Geral da AMM, em Estocolmo, Suécia, em Setembro de 1994 e com revisão editorial na $1700^{a}$ Sessão do Conselho, em Divonne-les-Bains, França, em Maio de 2005 e na 173. ${ }^{a}$ Sessão do Conselho, em Divonneles-Bains, França, Maio de 2006. 
"O Médico deve respeitar o direito do paciente à confidencialidade. É ético revelar informação confidencial quando o paciente consinta ou quando haja uma ameaça real e iminente para o paciente ou para terceiros e essa ameaça possa ser afastada pela quebra da confidencialidade." ${ }^{6}$

Código Internacional de Ética Médica ${ }^{7}$

\section{Parte 1. ${ }^{a} 0$ dever de sigilo médico}

\section{Segredo e confiança}

Após quase 2500 anos depois de Hipócrates, ${ }^{8}$ a obrigação do médico de guardar segredo mantém toda a actualidade e assume-se como, cada vez mais, uma necessidade.

O sigilo médico está no cerne da relação médico-paciente e é o pilar sobre que assenta esta relação pessoalíssima que exige, necessariamente, confiança. Com efeito - como escreveu L. Portes ${ }^{9}$ - "não existe medicina sem confiança, tal como não existe confiança sem confidências nem confidências sem segredo."

Num breve relance sobre a História, constatamos que o dever deontológico de segredo médico remonta a Hipócrates. Contudo, durante a Idade Média, este dever não era garantido no mundo Ocidental. Pelo contrário, sempre manteve a sua vigência na medicina árabe e judaica.

Na Idade Moderna, o segredo médico ressurge na Europa, fruto do pensamento iluminista, primeiro, e liberal, depois. Desde a Segunda Guerra mundial, a defesa do segredo médico parece seguir uma nova via inspirada pela defesa dos direitos humanos. Donde o surgimento de diversos textos nacionais e internacionais, que julgamos importante apresentar de seguida.

6 Na versão original, em inglês, "A physician shall respect a patient's right to confidentiality. It is ethical to disclose confidential information when the patient consents to it or when there is a real and imminent threat of harm to the patient or to others and this threat can be only removed by a breach of confidentiality."

7 O Código Internacional de Ética Médica da Associação Médica Mundial (World Medical Association International Code of Medical Ethics) foi adoptado pela 3. ${ }^{a}$ Assembleia Geral da Associação Médica Mundial em Londres, Inglaterra, em Outubro de 1949; e alterada pela 22. ${ }^{a}$ Assembleia Geral da AMM em Sidney, Austrália, em Agosto de 1968 e pela $35 .^{a}$ Assembleia Geral da AMM em Veneza, Itália, em Outubro de 1983 e pela Assembleia Geral da AMM, em Pilanesberg, África do Sul, em Outubro de 2006.

8 Hipócrates é considerado o mais ilustre médico da Antiguidade, nascido na ilha de Cós, viveu aproximadamente entre 460 e 377 a. C.

9 Apud Gilbert Hottois/ Marie-Hélène Parizeu, Dicionário de Bioética, Lisboa, p.330. 


\section{Fontes internacionais relativas ao Direito ao Sigilo Médico}

Em primeiro lugar, destacamos os documentos redigidos sob a égide das Nações Unidas:

Declaração Universal dos Direitos do Homem, de 10 de Dezembro de $1948^{10}$ Artigo 12. : "Ninguém sofrerá intromissões arbitrárias na sua vida privada, na sua família, no seu domicílio ou na sua correspondência, nem ataques à sua honra e reputação. Contra tais intromissões ou ataques toda a pessoa tem direito a protecção da lei."

\section{Pacto Internacional de Direitos Civis e Políticos ${ }^{11}$}

Artigo 17. ${ }^{\circ}$ "Ninguém será objecto de ingerências arbitrárias ou ilegais na sua vida privada, na sua família, no seu domicílio ou na sua correspondência, nem de ataques ilegais à sua honra e reputação."

No âmbito da UNESCO ${ }^{12}$ merecem atenção os seguintes documentos:

Declaração Universal sobre o Genoma Humano e os Direitos do Homem, de 11 de Novembro de $1997^{13}$, artigo $7 ; ;^{14}$

Declaração Internacional sobre Dados Genéticos Humanos, de 16 de Outubro de $2004^{15}$ (artigo $14 .^{\circ}$ - Vida privada e confidencialidade); ${ }^{16}$

10 Adoptada e proclamada pela Assembleia Geral da Organização das Nações Unidas (ONU) na sua Resolução 217A (III) de 10 de Dezembro de 1948. Publicada no Diário da República, I Série A, n. ${ }^{\circ}$ 57/78, de 9 de Março de 1978, mediante aviso do Ministério dos Negócios Estrangeiros.

11 Adoptado e aberto à assinatura, ratificação e adesão pela Resolução 2200A (XXI) da Assembleia Geral das Nações Unidas, de 16 de Dezembro de 1966. Aprovação para ratificação: Lei n. ${ }^{\circ}$ 29/78, de 12 de Junho, publicada no Diário da República, I Série A, n. ${ }^{\circ}$ 133/78 (rectificada mediante aviso de rectificação publicado no Diário da República n. ${ }^{\circ}$ 153/78, de 6 de Julho).

12 Organização das Nações Unidas para a Educação, Ciência e Cultura.

13 Adoptada pela Conferência Geral da UNESCO, em 11 de Novembro de 1997.

14 Artigo 7 - Dados genéticos associados a indivíduo identificável, armazenados ou processados para uso em pesquisa ou para qualquer outro uso, devem ter sua confidencialidade assegurada, nas condições estabelecidas pela legislação.

15 Adoptada pela Conferência Geral da UNESCO, em 16 de Outubro de 2003.

16 Artigo $14 .^{\circ}$ : Vida privada e confidencialidade (a) Os Estados deverão desenvolver esforços no sentido de proteger, nas condições previstas pelo direito interno em conformidade com o direito internacional relativo aos direitos humanos, a vida privada dos indivíduos e a confidencialidade dos dados genéticos humanos associados a uma pessoa, uma família ou, se for caso disso, um grupo identificável. (b) Os dados genéticos humanos, os dados proteómicos humanos e as amostras biológicas associados a uma pessoa identificável não deverão ser comunicados nem tornados acessíveis a terceiros, em particular empregadores, companhias de seguros, estabelecimentos de ensino ou família, se não for por um motivo de interesse público importante nos casos restritivamente previstos pelo direito interno em conformidade com o direito internacional relativo aos direitos humanos, ou ainda sob reserva de 
Declaração sobre Normas Universais em Bioética, de 19 de Outubro de $2005^{17}$ (artigo $9^{\circ}$ Vida privada e confidencialidade). ${ }^{18}$

Da Organização Mundial de Saúde, no domínio do direito ao sigilo médico, destaca-se:

\section{A Convenção da Organização das Nações Unidas sobre os Direitos da Criança, de $1989,{ }^{19}$ artigo $16 .{ }^{20}$}

A Declaração para a Promoção dos Direitos dos Pacientes, de 1994. ${ }^{21}$

A Associação Médica Mundial, sendo embora uma organização de direito privado, tem assumido um papel de grande relevo no plano da ética e direito

consentimento prévio, livre, informado e expresso da pessoa em causa, na condição de tal consentimento estar em conformidade com o direito interno e com o direito internacional relativo aos direitos humanos. A vida privada de um indivíduo que participa num estudo em que são utilizados dados genéticos humanos, dados proteómicos humanos ou amostras biológicas deverá ser protegida e os dados tratados como confidenciais. (c) Os dados genéticos humanos, os dados proteómicos humanos e as amostras biológicas recolhidos para fins de investigação médica e científica não deverão por norma estar associados a uma pessoa identificável. Mesmo quando esses dados ou amostras biológicas não estão associados a uma pessoa identificável, deverão ser tomadas as precauções necessárias para garantir a sua segurança. (d) Os dados genéticos humanos, os dados proteómicos humanos e as amostras biológicas recolhidos para fins de investigação médica e científica só podem manter-se associados a uma pessoa identificável se forem necessários para a realização da investigação e na condição de a vida privada do indivíduo e a confidencialidade dos referidos dados ou amostras biológicas serem protegidos em conformidade com o direito interno; (e) Os dados genéticos humanos e os dados proteómicos humanos não deverão ser conservados sob uma forma que permita identificar o indivíduo em causa por mais tempo que o necessário para alcançar os objectivos com vista aos quais foram recolhidos ou ulteriormente tratados.

17 Adoptada pela Conferência Geral da UNESCO, em 19 de Outubro de 2005. Com esta Declaração, pela primeira vez na história da bioética, os Estados-membros comprometeram-se, e à comunidade internacional, a respeitar e aplicar os princípios fundamentais da bioética condensados num texto único.

18 Artigo 90: "A vida privada das pessoas em causa e a confidencialidade das informações que lhes dizem pessoalmente respeito devem ser respeitadas. Tanto quanto possível, tais informações não devem ser utilizadas ou difundidas para outros fins que não aqueles para que foram coligidos ou consentidos, e devem estar em conformidade com o direito internacional, e nomeadamente com o direito internacional relativo aos direitos humanos."

19 Adoptada e aberta à assinatura, ratificação e adesão pela Resolução n. ${ }^{\circ}$ 44/25 da Assembleia Geral da ONU, de 20 de Novembro de 1989, Aprovada, para ratificação, pela Resolução da Assembleia da República n. ${ }^{\circ}$ 20/90, de 12 de Setembro.

20 Artigo 16: 1. Nenhuma criança pode ser sujeita a intromissões arbitrárias ou ilegais na sua vida privada, na sua família, no seu domicílio ou correspondência, nem a ofensas ilegais à sua honra e reputação. 2. A criança tem direito à protecção da lei contra tais intromissões ou ofensas.

21 Declaração sobre a Promoção dos Direitos dos Pacientes na Europa, Amesterdão, 28-30 de Março de 1994, Organização Mundial de Saúde, Secretaria Regional da Europa. 
médicos, gozando as suas Declarações de uma auctoritas que confere a esta forma de soft law um peso muito proeminente. ${ }^{22}$ Destacam-se:

A Declaração de Helsínquia $(1964)^{23}$ sobre princípios éticos aplicáveis às investigações médicas que incidam sobre sujeitos humanos;

A Declaração de Lisboa (1981) sobre os Direitos do Doente ${ }^{24}$ e a

A Declaração de Budapeste (1993) sobre Confidencialidade e Defesa do Paciente (Statement on Patient Advocacy and Confidentiality). ${ }^{25}$

Voltando-nos agora para o espaço do Continente europeu, devemos fazer referência ao direito do Conselho da Europa, por um lado, e ao direito da União Europeia, por outro.

No âmbito do Conselho da Europa devemos destacar os seguintes documentos:

Convenção Europeia dos Direitos do Homem, ${ }^{26}$ artigo $8 .^{\circ}$ (Direito ao respeito pela vida privada e familiar); ${ }^{27}$

Convenção sobre os Direitos do Homem e a Biomedicina ${ }^{28}$ (Artigo $10{ }^{\circ}$ Vida privada e direito à informação); ${ }^{29}$

22 Cfr. www.wma.net.

23 Adoptada em Helsínquia em Junho de 1964 e alterada em Tóquio em Outubro de 1975, em Veneza em Outubro de 1983, em Hong Kong em Setembro de 1989, em Somerset West (África do Sul) em Outubro de 1996 e em Edimburgo em Outubro de 2000. Foram ainda aditadas duas notas explicativas ao texto da Declaração, em Washington em 2002 e em Tóquio em 2004.

24 Adoptada em Lisboa em Setembro e Outubro de 1981 e alterada em Bali em Setembro de 1995.

25 Adoptada pela 45. a Assembleia Geral da AMM realizada em Budapeste, em Outubro de 1993, revista em Pilanesberg, África do Sul, em Outubro de 2006.

26 Convenção para a Protecção dos Direitos do Homem e das Liberdades Fundamentais. Aprovada para ratificação pela Lei n. ${ }^{\circ}$ 65/78, de 13 de Outubro, publicada no Diário da República, I Série, n. ${ }^{\circ}$ 236/78 (rectificada por Declaração da Assembleia da República publicada no Diário da República, I Série, n. ${ }^{\circ}$ 286/78, de 14 de Dezembro).

27 Artigo 8. ${ }^{\circ}:$ 1. Qualquer pessoa tem direito ao respeito da sua vida privada e familiar, do seu domicílio e da sua correspondência. 2. Não pode haver ingerência da autoridade pública no exercício deste direito senão quando esta ingerência estiver prevista na lei e constituir uma providência que, numa sociedade democrática, seja necessária para a segurança nacional, para a segurança pública, para o bem-estar económico do país, a defesa da ordem e a prevenção das infracções penais, a protecção da saúde ou da moral, ou a protecção dos direitos e das liberdades de terceiros.

28 Convenção para a Protecção dos Direitos do Homem e da Dignidade do Ser Humano relativamente às Aplicações da Biologia e da Medicina: Convenção sobre os Direitos do Homem e a Biomedicina. Adoptada e aberta à assinatura em Oviedo, a 4 de Abril de 1997. Ratificada por Portugal e Publicada no Diário da República - I Série-A N. ${ }^{\circ}$ 2, de 3 de Janeiro de 2001.

29 Artigo $10 .^{\circ}: 1$ - Qualquer pessoa tem direito ao respeito da sua vida privada no que toca a informações relacionadas com a sua saúde. 2 - Qualquer pessoa tem o direito de conhecer toda a informação recolhida sobre a sua saúde. Todavia, a vontade expressa por uma pessoa de não ser informada deve ser respeitada. 3 - A título excepcional, a lei pode prever, no interesse do paciente, restrições ao exercício dos direitos mencionados no n. ${ }^{\circ} 2$. 


\section{Convenção para a Protecção das Pessoas relativamente ao Tratamento Auto- matizado de Dados de Carácter Pessoal; ${ }^{30}$}

Recomendação N. ${ }^{\circ}$ R (81) 1 sobre os Bancos de Dados Médicos Automatizados; Recomendação N. ${ }^{\circ}$ R (97) 5 relativa à Protecção de Dados Médicos.

Por seu turno, no direito da União Europeia destacamos os seguintes documentos:

\section{A Carta dos Direitos Fundamentais da União Europeia: ${ }^{31}$}

A Directiva 95/46/CV do Parlamento Europeu e do Conselho, de 24 de Outubro, relativa à protecção das pessoas singulares no que diz respeito ao tratamento de dados pessoais e à livre circulação desses dados. ${ }^{32}$

O Parlamento Europeu aprovou a Carta Europeia dos Direitos dos Pacientes, ${ }^{33}$ na qual se enumeram um conjunto de direitos com vista a proteger a pessoa doente. Mais recentemente, foi anunciada a Carta Europeia dos Direitos do Paciente, redigida em 2002 pela Active Citizenship Network e que mereceu aprovação por parte do Comité Económico e Social Europeu. ${ }^{34}$

\section{0 sigilo médico no direito português}

\subsection{Direito Constitucional}

O princípio da dignidade da pessoa humana encabeça o ordenamento jurídico português. ${ }^{35}$ Deste princípio da dignidade da pessoa humana, de inspiração kantiana e iluminista, a Lei Fundamental apresenta um extenso leque de direitos fundamentais. $\mathrm{O}$ direito à reserva da intimidade da vida privada e familiar é protegido pelo artigo $26 .^{\circ}$ da Constituição da República

30 Adoptada e aberta à assinatura em Estrasburgo, a 1 de Fevereiro de 1981. Aprovada, para ratificação, pela Resolução da Assembleia da República n. ${ }^{\circ}$ 42/2001, de 25 de Junho.

31 O Tratado de Lisboa incorpora a Carta dos Direitos Fundamentais da União Europeia, pelo que estes direitos passaram a ter força normativa plena com a entrada em vigor do Tratado. Segundo o artigo 7. ${ }^{\circ}$ o Respeito pela vida privada e familiar: "Todas as pessoas têm direito ao respeito pela sua vida privada e familiar, pelo seu domicílio e pelas suas comunicações."

32 Esta Directiva foi transposta para o direito português, pela Lei n. ${ }^{\circ}$ 67/98, de 26 de Outubro.

33 Carta Europeia dos Direitos do Paciente, Resolução de 19 de Janeiro de 1984, JOCE C 46, de 20 de Fevereiro de 1984, p. 104.

34 Parecer do Comité Económico e Social Europeu sobre "Os direitos do paciente" (2008/C 10/18), de Janeiro de 2008. (Jornal Oficial da União Europeia, 15.1.2008, C 10/67 ss.)

35 Artigo $1^{\circ}$ (República Portuguesa): "Portugal é uma República soberana, baseada na dignidade da pessoa humana e na vontade popular e empenhada na construção de uma sociedade livre, justa e solidária." 
Portuguesa (CRP). "No plano filosófico, o respeito pelo segredo baseia-se num direito natural à intimidade que faz parte do desenvolvimento da pessoa. O segredo identifica-se com uma condição necessária à realização de certas relações interpessoais onde a intimidade entra em jogo: o respeito, o amor, a amizade, a confiança. O segredo concorre para o estatuto da pessoa humana, porquanto visa proteger a intimidade e o poder de autodeterminação do ser humano." 37

$\mathrm{O}$ direito à intimidade da vida privada e familiar inclui dois direitos menores: a) o direito a impedir o acesso de estranhos a informações sobre a vida privada e familiar; e b) o direito a que ninguém divulgue as informações que tenha sobre a vida privada e familiar de outrem, afirma Gomes Canotilho e Vital Moreira. ${ }^{38}$

Por outro lado, o direito à autodeterminação informacional ${ }^{39}$ e as regras básicas de protecção dos dados pessoais têm dignidade de tutela constitucional, no artigo 35. . ${ }^{40}$ Este artigo consagra um conjunto de direitos fundamentais, relacionados com o tratamento informático de dados pessoais, com destaque

36 “1. A todos são reconhecidos os direitos à identidade pessoal, (...) à reserva da intimidade da vida privada e familiar e à protecção legal contra quaisquer formas de discriminação. 2. A lei estabelecerá garantias efectivas contra a obtenção e utilização abusivas, ou contrárias à dignidade humana, de informações relativas às pessoas e famílias."

37 Gilbert Hottois/ Marie-Hélène Parizeau, Dicionário de Bioética, p.331.

38 Gomes Canotilho/ Vital Moreira, Constituição Anotada, 3. . edição revista, Coimbra, Coimbra Editora, 1993, p. 181.

39 Este direito - que brota do direito geral de personalidade - foi enunciado pelo Tribunal Constitucional alemão (Bundesverfassungsgericht) na decisão de 15 de Dezembro de 1983, que caracterizou este direito como a "faculdade de o indivíduo, a partir da autodeterminação, decidir basicamente sobre si mesmo quando e dentro de que limites pode revelar situações referentes à sua vida" e afirmou que se trata de "um direito fundamental que garante ao indivíduo a competência para em princípio ser ele próprio a decidir sobre a utilização e divulgação dos seus dados pessoais."

40 Artigo $35^{\circ}$ (Utilização da informática): 1. Todos os cidadãos têm o direito de acesso aos dados informatizados que lhes digam respeito, podendo exigir a sua rectificação e actualização, e o direito de conhecer a finalidade a que se destinam, nos termos da lei. 2. A lei define o conceito de dados pessoais, bem como as condições aplicáveis ao seu tratamento automatizado, conexão, transmissão e utilização, e garante a sua protecção, designadamente através de entidade administrativa independente. 3. A informática não pode ser utilizada para tratamento de dados referentes a convicções filosóficas ou políticas, filiação partidária ou sindical, fé religiosa, vida privada e origem étnica, salvo mediante consentimento expresso do titular, autorização prevista por lei com garantias de não discriminação ou para processamento de dados estatísticos não individualmente identificáveis. 4. É proibido o acesso a dados pessoais de terceiros, salvo em casos excepcionais previstos na lei. 5. É proibida a atribuição de um número nacional único aos cidadãos. 6. A todos é garantido livre acesso às redes informáticas de uso público, definindo a lei o regime aplicável aos fluxos de dados transfronteiras e as formas adequadas de protecção de dados pessoais e de outros cuja salvaguarda se justifique por razões de interesse nacional. 7. Os dados pessoais constantes 
para o direito ao sigilo, bem como a correspondente obrigação de confidencialidade que recai sobre os responsáveis pelos ficheiros e a proibição de acesso aos mesmos por terceiro. ${ }^{41}$

Por outro lado, o sigilo médico beneficia do regime especial, previsto no artigo $18 .^{\circ}$ da CRP ${ }^{42}$ dos direitos, liberdades e garantias: aplicação imediata, vinculação de todos os sujeitos de direito, públicos e privados, e restrições impostas apenas por lei e na medida do necessário para salvaguardar outros direitos ou interesses constitucionalmente protegidos.

\subsection{Legislação de direito da saúde}

O direito à confidencialidade da informação de saúde e o correspondente dever de guardar sigilo por parte do médico, de outros profissionais de saúde e ainda de outras pessoas cuja profissão está relacionada com a prestação de cuidados de saúde, está prevista em várias normas de diplomas específicos do direito da saúde. Façamos um elenco dos diplomas mais significativos.

\section{i. Lei de Bases da Saúde ${ }^{43}$}

A Lei de Bases da Saúde (Lei no 48/90, de 24 de Agosto) confere aos utentes o direito a: "d) Ter rigorosamente respeitada a confidencialidade sobre os dados pessoais revelados."

\section{ii.Regime jurídico aplicável à realização de ensaios clínicos com medicamentos de uso humano}

A Lei n. ${ }^{\circ}$ 46/2004, 19 de Agosto aprova o regime jurídico aplicável à realização de ensaios clínicos com medicamentos de uso humano ${ }^{44}$ contém normas sobre a confidencialidade (Artigo 43. ${ }^{\circ}$ ):

de ficheiros manuais gozam de protecção idêntica à prevista nos números anteriores, nos termos da lei.

41 Cfr. Helena Moniz, Notas sobre a protecção de dados pessoais perante a informática, RPCC, ano 7. ${ }^{\circ}$, II, Abril-Junho de 1997, 231-298, 245/261.

42 Artigo $18 .^{\circ}$ (Força jurídica) 1. Os preceitos constitucionais respeitantes aos direitos, liberdades e garantias são directamente aplicáveis e vinculam as entidades públicas e privadas. 2. A lei só pode restringir os direitos, liberdades e garantias nos casos expressamente previstos na Constituição, devendo as restrições limitar-se ao necessário para salvaguardar outros direitos ou interesses constitucionalmente protegidos. 3. As leis restritivas de direitos, liberdades e garantias têm de revestir carácter geral e abstracto e não podem ter efeito retroactivo nem diminuir a extensão e o alcance do conteúdo essencial dos preceitos constitucionais.

43 Lei n. ${ }^{\circ}$ 46/90, de 24 de Agosto, alterada pela Lei n. ${ }^{\circ} 27 / 2002$, de 8 de Novembro.

44 Este diploma transpõe para a ordem jurídica nacional a Directiva n. ${ }^{\circ}$ 2001/20/CE, do Parlamento Europeu e do Conselho, de 4 de Abril, relativa à aproximação das disposições legislativas, regulamentares e administrativas dos Estados membros respeitantes à aplicação de 
"Todos aqueles que, em qualquer qualidade, intervenham em ensaios ou que, por qualquer forma, tenham conhecimento da sua realização, ficam obrigados ao dever de sigilo sobre quaisquer dados pessoais a que tenham acesso."

\section{iii. Regime jurídico da colheita e transplante de órgãos e tecidos}

O regime jurídico da colheita e transplante de órgãos e tecidos está previsto na Lei n. ${ }^{\circ} 22 / 2007$, de 29 de Junho, ${ }^{45}$ e o seu artigo $4 .^{\circ}$ garante a confidencialidade nos seguintes termos: "1-Salvo o consentimento de quem de direito, é proibido revelar a identidade do dador ou do receptor de órgão ou tecido."

\section{iv. Procriação Medicamente Assistida}

Na lei sobre a procriação medicamente assistida (Lei n. ${ }^{\circ}$ 32/2006, de 31 de Julho) encontramos as seguintes regras sobre o sigilo médico. Segundo o art. $15 .^{\circ}$, n. $^{\circ} 1$ :

"Todos aqueles que, por alguma forma, tomarem conhecimento do recurso a técnicas de PMA ou da identidade de qualquer dos participantes nos respectivos processos estão obrigados a manter sigilo sobre a identidade dos mesmos e sobre o próprio acto da PMA."

$\mathrm{O}$ art. 43. ${ }^{\circ}$ pune a Violação do dever de sigilo ou de confidencialidade:

"Quem violar o disposto no artigo 15. é punido com pena de prisão até 1 ano ou com pena de multa até 240 dias."

Este tipo legal de crime em legislação extravagante merece alguma reflexão crítica. Ou esta norma está em situação de concurso aparente com o tipo fundamental de crime previsto no art. $195 .^{\circ}$ do Código Penal, ou visa alargar a punibilidade a "todos aqueles que, por alguma forma, tomarem conhecimento do recurso a técnicas de PMA ou da identidade de qualquer dos participantes nos respectivos processos." Ou seja, as pessoas podem ser punidas mesmo que não se enquadrem no filtro normativo do art. 195. ${ }^{\circ}$ do Código Penal: "segredo alheio de que tenha tomado conhecimento em razão do seu estado, ofício, emprego, profissão ou arte." Na primeira hipótese, trata-se de uma norma redundante; na segunda, poderá tratar-se de um alargamento da punibilidade excessivo e desproporcionado.

boas práticas clínicas na condução dos ensaios clínicos de medicamentos para uso humano, e estabelece o regime jurídico da realização de ensaios clínicos em seres humanos com a utilização de medicamentos de uso humano.

45 Este diploma que transpõe parcialmente para a ordem jurídica nacional a Directiva $n .^{\circ}$ 2004/23/CE, do Parlamento Europeu e do Conselho, de 31 de Março, alterando a Lei n. ${ }^{\circ}$ 12/93, de 22 de Abril, relativa à colheita e transplante de órgãos e tecidos de origem humana. 


\section{v. Educação sexual e acesso ao planeamento familiar}

A Lei n. ${ }^{\circ}$ 3/84, de 24 de Março, que regula a Educação sexual e acesso ao planeamento familiar prevê no artigo $15 .^{\circ}$ o dever de sigilo profissional:

"Os funcionários dos centros de consulta sobre planeamento familiar e dos centros de atendimento de jovens ficam sujeitos à obrigação de sigilo profissional sobre o objecto, o conteúdo e o resultado das consultas em que tiverem intervenção e, em geral, sobre actos ou factos de que tenham tido conhecimento no exercício dessas funções ou por causa delas."

\section{vi. Lei de Saúde Mental}

A Lei de Saúde Mental (Lei n. ${ }^{\circ}$ 36/98, de 24 de Julho), no artigo 5. ${ }^{\circ}$, relativo aos Direitos e deveres do utente, remete para a Lei de Bases da Saúde, não contendo nenhuma norma especial sobre confidencialidade.

\subsection{Cartas de Direitos dos Pacientes}

Estes documentos, embora não vinculativos, sintetizam de forma clara os direitos dos pacientes e contêm explicações muito úteis para os profissionais de saúde. A Carta dos Direitos e Deveres dos Doentes ${ }^{46}$ afirma: 9. "O doente tem direito à confidencialidade de toda a informação clínica e elementos identificativos que the respeitam." "47 No mesmo sentido, a Carta dos Direitos do Doente Internado ${ }^{48}$ dispõe: "9. $O$ doente internado tem direito à confidencialidade de toda a informação clínica e elementos identificativos que the respeitam." ${ }^{49}$

46 Direcção-Geral da Saúde: Carta dos Direitos e Deveres dos Doentes, Lisboa, 1998.

47 "Todas as informações referentes ao estado de saúde do doente - situação clínica, diagnóstico, prognóstico, tratamento e dados de carácter pessoal - são confidenciais. Contudo, se o doente der o seu consentimento e não houver prejuízos para terceiros, ou a lei o determinar, podem estas informações ser utilizadas. Este direito implica a obrigatoriedade do segredo profissional, a respeitar por todo o pessoal que desenvolve a sua actividade nos serviços de saúde."

48 Direcção-Geral da Saúde; Direcção de Serviços de Prestação de Cuidados de Saúde, Lisboa, 2005. O presente documento é uma especificação da Carta dos Direitos e Deveres dos Doentes. Cfr. http://dgsaude.pt

49 Explica esta Carta: “Todas as informações relativas ao doente - situação clínica, diagnóstico, prognóstico, tratamento e dados pessoais - são confidenciais. No entanto, se o doente der o consentimento e não houver prejuízo para terceiros, ou se a Lei o determinar podem estas informações ser utilizadas. O doente deve ser alertado para a necessidade de não colocar em risco a segurança ou a vida de outros. Este direito implica obrigatoriedade do segredo profissional, a respeitar por todo o pessoal que desenvolve a sua actividade no estabelecimento, incluindo o voluntário, que por força das funções que desempenha partilham informação. Os registos hospitalares devem ser mantidos em condições que assegurem a sua confidenciali- 


\subsection{Direito Penal}

O direito fundamental à intimidade da vida privada e familiar merece a protecção do Direito de ultima ratio que é o Direito Penal: o ramo jurídico que visa proteger os bens jurídicos fundamentais da vida em comunidade face às mais fortes e intoleráveis agressões (o que a doutrina dá o nome da subsidiariedade e fragmentariedade do Direito Penal)..$^{50}$

Na compreensão do conceito de privacidade a doutrina penalista portuguesa adopta a doutrina das três esferas ou dos três degraus, segundo a qual se deverá distinguir: a) a esfera da intimidade; b) a esfera da privacidade e c) a esfera da vida normal da relação..$^{51}$ "Na base do tipo legal de crime violação de segredo (art. 195. ${ }^{\circ}$ do CP) está o dever de confidencialidade, em que se pretende proteger, para lá do simples interesse comunitário da confiança na discrição e reserva, a privacidade em sentido material, isto é, a privacidade no seu círculo mais extenso, abrangendo não só a esfera da intimidade como a esfera da privacidade stricto senso." 52 Como veremos, o médico, outros profissionais de saúde, e outras pessoas no exercício da sua profissão, devem

dade, merecendo atenção especial os dados informatizados. Chama-se especialmente a atenção para que as informações prestadas pelo telefone, em que se desconhece o interlocutor, têm que ser verdadeiras mas tendo em conta a necessária confidencialidade. As declarações que se fazem aos média, nomeadamente, nos casos frequentes que envolvem personalidades públicas como por exemplo: desportistas, políticos e artistas só podem ser feitas com autorização do próprio e do Conselho de Administração da Instituição. As certidões deverão evitar incluir dados que possam prejudicar o doente ou terceiros, devendo nelas constar que foram passadas a pedido do doente ou de quem o representa, bem como o fim a que se destinam. Um indivíduo internado pode pedir que a sua presença no hospital não seja divulgada. $\mathrm{O}$ acesso de jornalistas, fotógrafos, publicitários e comerciantes deve estar condicionado à autorização prévia do doente e da direcção do estabelecimento. Os delegados de informação médica não devem entrar nas áreas de atendimento clínico. O segredo profissional tem por finalidade respeitar e proteger o doente. Deve ser salvaguardada a confidencialidade referente às crianças vítimas de maus-tratos no seio familiar pois pode pôr em risco a sua própria segurança."

50 Vide Jorge de Figueiredo Dias, Direito Penal: Parte Geral, Tomo 1: Questões Fundamentais, A Doutrina Geral do Crime, Coimbra, Coimbra Editora, 2004, p. 15 e ss.

51 Sobre a teoria das três esferas ou três degraus (Dreistufentheorie) vide, Manuel da Costa Andrade, Liberdade de Imprensa e Inviolabilidade Pessoal, Uma perspectiva Jurídico-Criminal, Coimbra, Coimbra Editora, 1996, p. 95 e ss. e no âmbito da doutrina juslaboral, vide Menezes Leitão, Código do Trabalho Anotado, Coimbra, Almedina, 2003, p. 38. Paulo Mota Pinto, $O$ direito à reserva sobre a intimidade da vida privada, Separata do Boletim da Faculdade de Direito, vol. 69 (1993) não concorda que a teoria das três esferas se aplique, sem reservas, no direito português.

52 Helena Moniz, "Segredo Médico, Acórdão da Relação de Coimbra de 5 de Julho de 2000 e Acórdão da Relação do Porto de 20 de Setembro de 2000," Revista Portuguesa de Ciência Criminal, Ano 10, Fasc. 4. ${ }^{\circ}$, Outubro - Dezembro, 2000, p. 636. 
guardar confidencialidade relativamente não só aos dados sobre a saúde, como sobre outros aspectos relativos à vida privada do paciente.

Segundo Helena Moniz, fazem parte da esfera íntima da pessoa: os dados relativos à filiação, residência, número de telefone, estado de saúde, vida conjugal, amorosa e afectiva, os factos que decorrem dentro do lar, as informações transmitidas por carta ou outros meios de telecomunicações, os factos passados que caíram no esquecimento, etc. ${ }^{53}$

Assim, os dados relativos ao estado de saúde merecem a mais forte proteç̧ão. Neste sentido, podemos constatar que a Lei de Protecção de Dados Pessoais (Lei $n^{\circ}$ 67/98 de 26 de Outubro) prevê um regime especial para os dados de saúde, considerando-os "dados sensíveis" (artigo 7..$^{\circ}$ e impondo "medidas especiais de segurança" (artigo 15..$^{\circ}$ ), quando esses dados forem objecto de tratamento, o que demonstra a natureza especialmente protegida destas informações.

No âmbito da relação clínica, o médico tem conhecimento de factos que pertencem à área de confidencialidade e reserva, mesmo à área da intimidade. A sua revelação ou divulgação arbitrárias (sem consentimento do paciente) e não justificadas "configuram um atentado socialmente intolerável a bens jurídicos criminalmente tutelados. E podendo, como tal, ser punida já a título de Devassa da vida privada (artigo 192. ${ }^{\circ}$ do Código Penal), já sob a forma de Violação de segredo (artigo 195. ${ }^{\circ}$ do Código Penal)." ${ }^{54}$

\section{i. Devassa da vida privada}

Este crime está previsto no artigo 192. ${ }^{\circ}$ (Devassa da vida privada), que prescreve:

1. Quem, sem consentimento e com intenção de devassar a vida privada das pessoas, designadamente a intimidade da vida familiar ou sexual:

a) Interceptar, gravar, registar, utilizar, transmitir ou divulgar conversa, comunicação telefónica, mensagens de correio electrónico ou facturação detalhada;

b) Captar, fotografar, filmar, registar ou divulgar imagem das pessoas ou de objectos ou espaços íntimos;

c) Observar ou escutar às ocultas pessoas que se encontrem em lugar privado; ou $d$ ) Divulgar factos relativos à vida privada ou a doença grave de outra pessoa; é punido com pena de prisão até um ano ou com pena de multa até 240 dias.

53 Helena Moniz, "Notas Sobre a Protecção de Dados Pessoais perante a Informática", Rev. Port. Ciência Criminal, ano 7. ${ }^{\circ}$, n. ${ }^{\circ}$ 2, 1997, p. 237.

${ }_{54}$ Costa Andrade, Direito Penal Médico, 2004, p.162. 
O crime de devassa da vida privada é um crime comum, isto é, não depende da qualidade específica do agente. Quando o agente é um médico (ou outro profissional obrigado a sigilo), verifica-se uma relação de concurso aparente com o crime de violação de segredo (artigo 195. o do Código Penal).

A vida privada das pessoas merece a protecção do direito penal, e isto independentemente do carácter desonroso ou não desses factos. O bem jurídico que aqui está em jogo é a privacidade e não a honra. Por outro lado, o direito pretende evitar não apenas o acesso à informação (alíneas a) a c), mas também a divulgação desses factos (al. d).

\section{ii. $O$ crime de violação de segredo}

O tipo legal com crime previsto no artigo $195 .^{\circ}$ do Código Penal protege o bem jurídico individual privacidade e também o bem jurídico supra-individual prestígio e confiança em determinadas profissões:

Artigo 195. ${ }^{\circ}$ (Violação de segredo):

Quem, sem consentimento, revelar segredo alheio de que tenha tomado conhecimento em razão do seu estado, ofício, emprego, profissão ou arte é punido com pena de prisão até um ano ou com pena de multa até 240 dias.

Relativamente à factualidade típica, isto é, os factos que se devem verificar para se poder afirmar estarmos perante o tipo legal de crime, devemos enunciar os seguintes:

1) Terá que se tratar de um segredo, isto é:

a) Tratar-se de factos conhecidos de um número circunscrito de pessoas (que não sejam do conhecimento público ou de um círculo alargado de pessoas ou que não seja um facto notório);

b) Que haja vontade de que os factos continuem sob reserva e

c) Existência de um interesse legítimo, razoável ou justificado na reserva; ${ }^{55}$

2) Terá que ser um segredo alheio (do paciente ou de terceiro);

3) Obtido no exercício da profissão: "só é segredo médico aquilo que o médico sabe de outra pessoa, apenas porque é médico;" "não é segredo penalmente relevante aquilo que o agente conhece em veste puramente "privada".

Se o médico revelar informações sobre a saúde do paciente a terceiros está preenchido o tipo legal de crime. E a ilicitude verificar-se-á se não houver

55 O interesse na protecção da reserva não tem que ser um interesse público, nem um interesse eticamente positivo, nem um interesse juridicamente louvável; "também as fraquezas humanas, as condutas imorais e mesmo os crimes podem valer como segredo." Costa Andrade, Comentário, I. 
qualquer causa de justificação. Trata-se de um crime semi-público, pelo que é necessária a apresentação de queixa. ${ }^{56}$

O Código Penal alemão, ${ }^{57}$ no $§ 203$ StGB, refere-se à "violação de segredo da esfera privada", abrangendo o segredo revelado ao médico ou conhecido por ele de outra forma. Este artigo não abrange apenas o segredo médico. Ao contrário da norma portuguesa, o tipo legal de crime alemão contém uma lista detalhada e extensa de todos aqueles que podem estar sujeitos à obrigação de segredo ${ }^{58}$ e, como destaca Peter Hünerfeld, ${ }^{59}$ abrange os membros de uma seguradora que realiza seguros de saúde, de acidente e de vida, ou de pessoas que realizam a contabilidade do médico privado. Está também expressamente prevista a punição da revelação não autorizada de segredo depois da morte do interessado.

\subsection{Direito Civil}

No plano civilístico, o direito ao sigilo médico enquadra-se no âmbito dos direitos de personalidade. Os direitos de personalidade são direitos absolutos, que impõem não apenas uma obrigação passiva universal, mas ainda um dever de respeito.

$\mathrm{O}$ direito ao sigilo pode radicar em duas fontes, quer no direito-quadro que é o direito geral de personalidade, consagrado na lei, no artigo $70 .^{\circ},{ }^{60}$ quer no direito especial da personalidade, consagrado no artigo $800^{\circ}$, o direito à reserva sobre a intimidade da vida privada.

Nas palavras de Orlando de Carvalho, o direito geral de personalidade consiste "(n)um direito à personalidade no seu todo, direito que abrange todas as manifestações previsíveis e imprevisíveis da personalidade, pois é, a um tempo, direito à pessoa-ser e à pessoa-devir, ou melhor, à pessoa-ser em devir, entidade não estática mas dinâmica e com jus à sua "liberdade de desabrochar" (com direito ao 'livre desenvolvimento da personalidade' de que falam já certos textos jurídicos). Trata-se de um jus in se ipsum radical, em

56 Cf. artigo $198 .^{\circ}$ do Código Penal.

57 Código Penal de 15 de Maio de 1871 na redacção publicada em 13-11-1998.

58 Em Portugal, como vimos, o tipo legal de crime é muito aberto, recorrendo-se a uma cláusula geral. O princípio da tipicidade assume assim uma grande - quiçá excessiva - elasticidade.

59 Peter Hünerfeld, Esfera Privada e Segredo, Revista Portuguesa de Ciência Criminal, Ano 14, n. ${ }^{\circ}$ s 1 e 2, Janeiro-Junho 2004, p. 198.

60 Artigo $70^{\circ}$ - Tutela geral da personalidade 1. A lei protege os indivíduos contra qualquer ofensa ilícita ou ameaça de ofensa à sua personalidade física ou moral. 2. Independentemente da responsabilidade civil a que haja lugar, a pessoa ameaçada ou ofendida pode requerer as providências adequadas às circunstâncias do caso, com o fim de evitar a consumação da ameaça ou atenuar os efeitos da ofensa já cometida. 
que a pessoa é o bem protegido, correspondendo à sua necessidade intrínseca de autodeterminação (...). Só um tal direito ilimitado e ilimitável permite uma tutela suficiente do homem ante os riscos de violação que lhe oferece a sociedade moderna". ${ }^{61}$

Para além da referida tutela geral, encontramos um direito especial de personalidade no próprio Código Civil. ${ }^{62} \mathrm{O}$ artigo $800^{\circ}$ (Direito à reserva sobre a intimidade da vida privada) dispõe:

1. Todos devem guardar reserva quanto à intimidade da vida privada de outrem.

2. A extensão da reserva é definida conforme a natureza do caso e a condição das pessoas.

$\mathrm{O}$ artigo $483 .^{\circ}$ sanciona com o dever de indemnizar a violação de direitos de outrem, nomeadamente os direitos de personalidade. Provando-se o comportamento ilícito e culposo do médico, pode o lesado intentar uma acção de indemnização solicitando o ressarcimento dos danos patrimoniais e não patrimoniais decorrentes do ilícito praticado.

A violação dos direitos de personalidade dá lugar não só a responsabilidade civil mas também a "providências (judiciais) adequadas às circunstâncias do caso, com o fim de evitar a consumação da ameaça ou atenuar os efeitos da ofensa já cometida”, nos termos dos artigos $70^{\circ}$, n. ${ }^{\circ} 2$ do Código Civil e artigos $1474^{\circ}$ e ss. do Código de Processo Civil.

\subsection{Direito do Trabalho}

O sigilo médico assume uma importância extraordinária no mundo do trabalho, já que a ilegítima quebra do sigilo, neste domínio, é a fonte de discriminação e de estigmatização das pessoas. ${ }^{63} \mathrm{O}$ Código do Trabalho de 2003 consagra uma subsecção relativa aos direitos de personalidade (artigos $15 .^{\circ}$ a $\left.21 .^{\circ}\right)$. O artigo $16 .^{\circ}$ do Código do Trabalho consagra o direito à reserva da intimidade da vida privada. ${ }^{64}$

61 Orlando de Carvalho, Teoria Geral do Direito Civil, Coimbra, 1981, p. 90. Rabindranath Capelo de Sousa, Direito Geral de Personalidade, Coimbra, Coimbra Editora, 1995.

62 Os artigos $75 .^{\circ}$ a $78 .^{\circ}$, relativos a cartas-missivas, memórias familiares e outros escritos confidenciais também visam proteger o bem jurídico segredo.

${ }^{63}$ Cfr. André Gonçalo Dias Pereira, "Discriminação de um trabalhador portador de VIH/SIDA: estudo de caso", Lex Medicinae - Revista Portuguesa de Direito da Saúde, N. o 6, 2006, pp. 121-135 e André Gonçalo Dias Pereira, "Cirurgião Seropositivo: do Pânico ao Direito", Lex Medicinae - Revista Portuguesa de Direito da Saúde, Ano 4, n. ${ }^{\circ}$, 2007, 97-114.

64 Artigo 16. (Reserva da intimidade da vida privada) 1 - O empregador e o trabalhador devem respeitar os direitos de personalidade da contraparte, cabendo-lhes, designadamente, guardar reserva quanto à intimidade da vida privada. 2 - $\mathrm{O}$ direito à reserva da intimidade da 
Por outro lado, o artigo 17. ${ }^{\circ}$, n. ${ }^{\circ} 2$ não permite que o empregador possa exigir "ao candidato a emprego ou ao trabalhador que preste informações relativas à sua saúde ou estado de gravidez, salvo quando particulares exigências inerentes à natureza da actividade profissional o justifiquem e seja fornecida por escrito a respectiva fundamentação.” Acresce que o empregador não tem o direito de tomar conhecimento sobre o estado de saúde do trabalhador, competindo ao médico atestar a sua aptidão ou não para o trabalho e disso informar a entidade patronal. ${ }^{65}$ Nesse sentido, ${ }^{66}$ dispõe o artigo $19 .{ }^{\circ}$, n. ${ }^{\circ} 3$, do Código do Trabalho: "O médico responsável pelos testes e exames médicos só pode comunicar ao empregador se o trabalhador está ou não apto para desempenhar a actividade, salvo autorização escrita deste."67

A própria ficha clínica é objecto de protecção legal reforçada. O artigo 247. ${ }^{\circ}$, n. ${ }^{\circ} 2$ da Lei n. ${ }^{\circ}$ 35/2004, de 29 de Julho, que regulamenta o Código do Trabalho, prescreve: "A ficha clínica está sujeita ao segredo profissional, só podendo ser facultada às autoridades de saúde e aos médicos da InspecçãoGeral do Trabalho." 68

Numa palavra: para além do comando constitucional e da legislação geral, o Direito impõe ao médico, no âmbito da medicina do trabalho, especiais exigências de confidencialidade.

vida privada abrange quer o acesso, quer a divulgação de aspectos atinentes à esfera íntima e pessoal das partes, nomeadamente relacionados com a vida familiar, afectiva e sexual, com o estado de saúde e com as convicções políticas e religiosas.

Segundo Guilherme Dray, in Pedro Romano Martinez/ Luís Monteiro/ Joana Vasconcelos/ Pedro Brito/ Guilherme Dray / Luís Silva, Código do Trabalho, 3. ${ }^{a}$ edição, Coimbra, Almedina, 2004, p. 102. esta norma vai (aparentemente) mais longe do que o art. $80 .^{\circ}$ do Código Civil visto que abrange "quer o acesso, quer a divulgação de aspectos atinentes à esfera íntima e pessoal das partes, o que significa que para além da intromissão, também a difusão de tais elementos não é permitida." Note-se que na doutrina juscivilista Paulo Mota Pinto, "O direito à reserva sobre a intimidade da vida privada," BFD, 69 (1993), p. 531, já defendia esta distinção.

65 Artigo $17 .^{\circ}$, n. $^{\circ} 3$. As informações previstas no número anterior são prestadas a médico, que só pode comunicar ao empregador se o trabalhador está apto ou não apto a desempenhar a actividade, salvo autorização escrita deste.

66 Esta regra foi claramente enunciada no Acórdão do Tribunal Constitucional n. ${ }^{\circ}$ 306/03, de 25 de Junho de 2003. Veja-se também o Parecer da Comissão Nacional de Protecção de Dados (Parecer n. ${ }^{\circ}$ 8/2003) - sobre o Novo Código do Trabalho.

67 Para uma crítica da possibilidade de o trabalhador dar o seu consentimento, vide José João Abrantes, "O novo Código do Trabalho e os direitos de personalidade do trabalhador", in Estudos sobre o Código do Trabalho, Coimbra Editora, 2004, p. 165, n. 52 e o Parecer Comissão Nacional de Protecção de Dados n. ${ }^{\circ}$ 8/2003 - sobre o Novo Código do Trabalho da Comissão Nacional de Protecção de Dados.

${ }^{68}$ Cfr. ainda os artigos $248 .^{\circ}$ e $249 .^{\circ}$ do mesmo diploma. 


\subsection{Normas dos Códigos Deontológicos}

O anterior Código Deontológico da Ordem dos Médicos ${ }^{69}$ não havia sido aprovado por um órgão com poderes legislativos, nem sequer fora publicado no Diário da República, mas antes apenas na Revista da Ordem dos Médicos. ${ }^{70}$ Por tal razão, o valor jurídico do CDOM era discutido na doutrina. ${ }^{71}$

Em Novembro de 2008, foi aprovado o novo Código Deontológico da Ordem dos Médicos, que regula o segredo médico nos artigos $85 .^{\circ}$ a $93 .^{\circ} \mathrm{e}$ este Código viria a ser publicado no Diário da República, 2. ${ }^{a}$ série $\quad N .^{\circ} 8 \quad 13$ de Janeiro de 2009 sob a forma de Regulamento n. ${ }^{\circ}$ 14/2009. Não será isento de reparos a forma legal - regulamento - escolhida para trazer ao Diário da República este importante documento normativo, na medida em que versa, limita e condiciona o exercício de direitos, liberdades e garantias, os quais nos termos do art. $18 .^{\circ}$ da CRP deveriam ser regulados por uma lei em sentido formal. Assim sendo, este Código Deontológico não pode prevalecer sobre a lei, que goza de valor normativo superior ao regulamento. A título de exemplo, o facto de o Código Deontológico autorizar a maternidade de substituição nos termos do art. $65 .^{\circ}$, n. $^{\circ} 3$ do $\mathrm{CDOM}$ de 2008 , não torna lícita esta prática que é claramente proibida pelo art. $8 .^{\circ}$ da Lei n. ${ }^{\circ} 32 / 2006$, de 26 de Julho, que regula a Procriação Medicamente Assistida. ${ }^{72}$

O sigilo faz parte do estatuto profissional dos médicos e da deontologia que rege a respectiva actividade. $\mathrm{O}$ doente só revelará os detalhes pessoais se tiver a segurança e a confiança de que o médico os não revelará a terceiros. "O médico é o confidente necessário do doente. Este tem de lhe revelar aspectos íntimos para que o clínico possa proceder a um diagnóstico correcto, primeiro passo para se alcançar o resultado desejado." ${ }^{73}$ Neste sentido, o Capítulo XI do CDOM regula a matéria do segredo profissional e o art. $85^{\circ}$ afirma como princípio geral: "O segredo médico é condição essencial ao relacionamento

${ }^{69}$ Cfr. http://www.ordemdosmedicos.pt

70 Ordem dos Médicos: Código Deontológico da Ordem dos Médicos, Revista da Ordem dos Médicos, n. ${ }^{\circ}$ 3; 1985: 1-28.

71 Cfr. André Gonçalo Dias Pereira, O Consentimento Informado na Relação Médico-Paciente. Estudo de Direito Civil, Publicações do Centro de Direito Biomédico, 9, Coimbra, Coimbra Editora, 2004, pp.101 ss.

72 Sobre este diploma, vide André Gonçalo Dias Pereira, "A Procriação Medicamente Assistida em Portugal, à Luz da Lei n. ${ }^{\circ}$ 32/2006, de 26 de Julho”, Revista Brasileira de Direito Médico e da Saúde (2007) n. ${ }^{\circ}$ 8, pp. 107-131 e Vera Raposo/ André Pereira, "Primeiras Notas Sobre A Lei Portuguesa De Procriação Medicamente Assistida (Lei n. ${ }^{\circ}$ 32/2006, de 26 de Julho)," Lex Medicinae: Revista Portuguesa de Direito da Saúde, 2006, n. ${ }^{\circ}$ 6, pp. 89-104.

73 Luís Vasconcelos Abreu, O segredo médico no direito português vigente, in Estudos de Direito da Bioética, Coimbra, Almedina, 2005, p. 267. 
médico-doente, assenta no interesse moral, social, profissional e ético, e pressupõe e permite uma base de verdade e de mútua confiança."

Na raiz da protecção da confidencialidade médica está a não revelação de segredos conhecidos no exercício da profissão, em ordem a proteger a esfera de segredo e de privacidade do paciente. ${ }^{74} \mathrm{O}$ Código Deontológico procura incluir no âmbito de protecção do segredo profissional factos a que o médico tenha acesso privilegiado pela conversa e observação do doente.

Artigo $86^{\circ}$ (Âmbito do segredo médico)

1. O segredo médico impõe-se em todas as circunstâncias dado que resulta de um direito inalienável de todos os doentes.

2. O segredo médico abrange todos os factos que tenham chegado ao conhecimento do médico no exercício da sua profissão ou por causa dela e compreende especialmente:

a) Os factos revelados directamente pela pessoa, por outrem a seu pedido ou por terceiro com quem tenha contactado durante a prestação de cuidados ou por causa dela;

b) Os factos apercebidos pelo médico, provenientes ou não da observação clínica do doente ou de terceiros;

c) Os factos resultantes do conhecimento dos meios complementares de diagnóstico e terapêutica referentes ao doente;

d) Os factos comunicados por outro médico ou profissional de saúde, obrigado, quanto aos mesmos, a segredo médico.

3. A obrigação de segredo médico existe, quer o serviço solicitado tenha ou não sido prestado e quer seja ou não remunerado.

4. O segredo médico mantém-se após a morte do doente;

5. É expressamente proibido ao médico enviar doentes para fins de diagnóstico ou terapêutica a qualquer entidade não vinculada ao segredo médico.

Daqui resulta que o segredo abrange não apenas os factos conhecidos directa e exclusivamente no exercício da profissão médica, ${ }^{75}$ mas ainda o conjunto de factos de que o médico teve conhecimento porque era médico. Nesse sentido aponta quer o citado artigo $86^{\circ}$ do CDOM, quer o artigo 195..$^{\circ}$ do Código Penal ${ }^{76}$, quer, no plano do direito civil, o princípio da boa

74 Adolf Laufs/ Wilhelm Uhlenbruck, Handbuch des Arztrechts, 3. Auflage, München, 2002, p. 548. Nesse sentido, dispõe o ARTIGO 67. ${ }^{\circ}$ (Segredo profissional): "O segredo profissional impõe-se a todos os Médicos e constitui matéria de interesse moral e social."

75 Cfr. João Álvaro Dias, Responsabilidade, informação, consentimento e confidencialidade, Revista Portuguesa do Dano Corporal, Ano II, n. ${ }^{\circ}$ (Maio de 1994), pp. 9-32, 28 e Procriação assistida e Responsabilidade Médica, Coimbra, Coimbra Editora, 1996, pp. 303/304.

76 Manuel da Costa Andrade, Comentário ao artigo 195..$^{\circ}$ do Código Penal, in Comentário Conimbricense ao Código Penal, (dirigido por Jorge de Figueiredo Dias), Parte Especial, Tomo I, Coimbra, Coimbra Editora, 1999, 771-802, (771-783). 
fé. ${ }^{77}$ "Assim, quando um doente encontra ocasionalmente o seu médico e lhe confia dados relativos ao seu estado de saúde ou sempre que uma pessoa, num qualquer evento social, contacta com um médico e, atendendo aos especiais conhecimentos deste, lhe revela pormenores ligados à sua saúde que não confiaria a mais ninguém que não fosse médico, nestas hipóteses há um investimento de confiança na discrição do médico, que parece perfeitamente justificado atento o conhecimento geral da existência de uma deontologia médica e, nela, do sigilo profissional."78

A violação dos deveres deontológicos origina responsabilidade disciplinar. Qualquer interessado pode participar esse facto junto da Ordem dos Médicos os factos, instaurando-se o competente processo. ${ }^{79}$

\section{Bens jurídicos protegidos}

No plano clínico, o segredo é necessário ao procedimento e ao diagnóstico. O médico precisa de saber tudo para intervir com competência. "Donde seja indispensável que ao paciente seja assegurado que as confidências permanecerão no segredo, para que possa falar livremente. Semelhante compromisso permite estabelecer uma relação de confiança necessária a uma acção terapêutica rigorosa e coerente. Assim, a regra do segredo pode ser entendida como um valor instrumental visando a realização de fins imediatos (a saúde) e remotos (a humanidade no homem)." 80

Quando as normas jurídicas estabelecem o dever de sigilo e garantem a confidencialidade das informações médicas não o fazem apenas para proteger a intimidade ou privacidade dos pacientes. Visam também proteger a própria dignidade da profissão médica e a confiança da sociedade e dos pacientes na medicina e nos profissionais de saúde. Donde, a extrema importância desta matéria para manter um bom sistema de saúde e para garantir a qualidade da assistência médica.

O segredo médico também visa promover interesses colectivos de saúde pública e de prestígio da medicina. Se houvesse falta de confiança na discrição dos médicos ou se não houvesse garantias de confidencialidade, muitos doentes, nomeadamente os portadores de doenças transmissíveis, poderiam abster-se de procurar cuidados de saúde, assim causando, consciente ou inconscientemente, o contágio de familiares e outros cidadãos.

77 Luís Vasconcelos Abreu, O segredo médico no direito português vigente, 2005, p. 267-268

78 Luís Vasconcelos Abreu, O segredo médico no direito português vigente, 2005, p. 268.

79 Vide o Estatuto Disciplinar dos Médicos (aprovado pelo DL 217/94 de 20 de Agosto): artigos $6^{\circ}$, n. $^{\circ} 2$ e $7^{\circ}$.

80 Gilbert Hottois/ Marie-Hélène Parizeu, Dicionário de Bioética, Lisboa, p.331. 
Perante estes dois fundamentos, um de carácter mais personalista outro mais comunitarista, a doutrina moderna defende a primazia do primeiro. $\mathrm{O}$ dever de sigilo médico é o reverso do direito fundamental à intimidade da vida privada do paciente, por outro lado, este dever é estruturante e fundante da relação jurídica médico-paciente. ${ }^{81}$

No mesmo sentido, no direito penal português, “(...) tudo se conjuga no sentido da prevalência ou primado da dimensão pessoal-individual, isto é, da elevação da privacidade à categoria de bem jurídico típico (...)". Costa Andrade invoca o elemento sistemático, o elemento literal e o elemento histórico (conversão em crime semi-público). Assim, o Bem Jurídico no direito português é a Privacidade em sentido material, ou seja, actos e factos que, não sendo secretos em si mesmos, devem subtrair-se à curiosidade pública: sentimentos, acções e abstenções. Mas apenas na medida em que é mediatizada por um segredo profissional. Sendo que, em segunda linha, é possível identificar a tutela de valores comunitários como o prestígio e a confiança em determinadas profissões (cf. artigo 135. ${ }^{\circ}$, n. ${ }^{\circ} 5$ do Código de Processo Penal). ${ }^{82}$

Na Alemanha, afirma-se que os bens jurídicos protegidos são o direito à intimidade da vida privada e também o direito à autodeterminação informacional.

\section{Objecto e conteúdo do dever de segredo médico}

Segredo vem do latim "secretu" e significa aquilo que deve estar oculto, secreto. ${ }^{83}$ Só os factos sigilosos, os factos que não são conhecidos de terceiros, são objecto do dever de segredo. "O carácter reservado não emerge da obrigação de segredo, mas esta daquele." ${ }^{84}$

As informações relativas à saúde de uma pessoa fazem parte da sua vida privada. ${ }^{85}$ Porém, o dever de segredo não abrange apenas as informações de saúde. ${ }^{86}$ "No ambiente de saúde ou de serviços sociais, o segredo médico define-se geralmente como uma regra deontológica que impõe a obrigação de discrição a qualquer indivíduo depositário, pelas suas funções, das informações

81 Cfr. Luís Vasconcelos Abreu, O segredo médico no direito português vigente, 2005, p. 270.

82 Cf. Costa Andrade, Comentário Conimbricense ao Código Penal, I, 1999, pp. 771 e ss.

83 Dicionário Lello.

84 Luís Vasconcelos Abreu, O segredo médico no direito português vigente, 2005, p. 274.

85 Paulo Mota Pinto, O direito à reserva da intimidade da vida privada, BFDUC, 1993, 479-585, 527.

86 A informação de saúde está definida na Lei de informação genética e informação pessoal de saúde (Lei n. ${ }^{\circ}$ 12/2005, de 26 de Janeiro): Artigo 2. (Informação de saúde) "Para os efeitos desta lei, a informação de saúde abrange todo o tipo de informação directa ou indirectamente ligada à saúde, presente ou futura, de uma pessoa, quer se encontre com vida ou tenha falecido, e a sua história clínica e familiar. 
que lhe são confiadas. A obrigação não abrange apenas as confidências mas também os factos descobertos no exercício, ou por ocasião do exercício, da profissão." 87

\section{i. Objecto do dever de segredo}

O objecto do dever de segredo abrange, designadamente:

A doença, a anamnese, o diagnóstico, a prognose, a prescrição, a terapia, a resposta ao medicamento, etc;

Os exames e meios de diagnóstico e toda a informação constante de relatórios, ficheiros, processos clínicos, radiografias, ecografias e tumografia computorizada; As alternativas e os métodos de tratamento;

Hábitos de vida;

A situação económica ou profissional do paciente;

Características físicas e psicológicas do doente;

Os traços de carácter revelados pelo paciente, as suas reacções aos diferentes actos médicos;

Os factos atinentes à sua vida privada, profissional, à situação económica, financeira ou política;

Os gostos, vícios, abusos, excessos e actos ilícitos. ${ }^{88}$

E pode mesmo abranger mais aspectos, de acordo com a experiência jurisprudencial alemã, o segredo médico abrange o nome do paciente; ${ }^{89} \mathrm{o}$ facto da própria consulta ou tratamento; as circunstâncias (hora, acompanhantes, tipo de viatura) em que um paciente chega ao hospital e que permitam identificá-lo; a capacidade para fazer testamento; doença venérea; consumo de estupefacientes; seropositividade; a defloração, feridas e cicatrizes..$^{90}$

87 Gilbert Hottois/ Marie-Hélène Parizeu, Dicionário de Bioética, p.328.

88 Cfr. Laufs/ Uhlenbruck, Handbuch des Arztrechts, p. 550 e Costa Andrade, Direito Penal Médico, 2004, p. 184-185.

89 Helena Moniz, "Segredo Médico, Acórdão da Relação de Coimbra de 5 de Julho de 2000 e Acórdão da Relação do Porto de 20 de Setembro de 2000," Revista Portuguesa de Ciência Criminal, Ano 10, Fasc. $4 .^{\circ}$, Outubro - Dezembro, 2000, p. 641, entende que a identificação, em princípio, por si só, não constitui uma informação no âmbito do segredo profissional. Todavia, em casos especiais, a identidade do paciente é protegida pelo sigilo médico. Assim acontece no âmbito da Lei n. ${ }^{\circ} 30 / 2000$, de 29 de Novembro, relativa ao regime jurídico aplicável ao consumo de estupefacientes e substâncias psicotrópicas. Segundo o art. 3. ${ }^{\circ}$ é garantido ao consumidor que solicita o tratamento espontâneo "o sigilo, estando os médicos, técnicos e restante pessoal de saúde que assistam o consumidor sujeitos ao dever de segredo profissional, não sendo obrigados a depor em inquérito ou processo judicial ou a prestar informações sobre a natureza e evolução do processo terapêutico ou sobre a identidade do consumidor."

90 A. Laufs/ W. Uhlenbruck, Handbuch des Arztrechts, p. 551 


\section{ii. Segredo de terceiro}

Os segredos de terceiro também são abrangidos pelo dever de confidencialidade. Trata-se de factos relativos à vida privada de um terceiro, que presumivelmente os quer manter sob reserva. "E aqui também podem estar em causa factos relativos à saúde - v.g. a confidência ao médico que o seu cônjuge é seropositivo. Ou factos relativos a outras áreas da vida privada do terceiro. Como acontece com o paciente que conta ao médico que o chefe do seu serviço mantém relações sexuais extraconjugais; ou aqueloutro que conta ao psiquiatra os excessos do seu cônjuge." ${ }^{11}$

\section{iii. Conteúdo do dever de segredo}

Por seu turno, o conteúdo do dever de segredo inclui:

Uma obrigação negativa: a obrigação de não revelar as informações cobertas pelo sigilo profissional a terceiros.

Uma obrigação positiva: adopção de precauções necessárias para que os mesmos terceiros não tenham acesso aos elementos sigilosos, por exemplo no que se refere à organização das instalações, do consultório. Esta obrigação positiva é posta em destaque na legislação relativa à protecção de dados pessoais e à informação de saúde pessoal. ${ }^{92}$ Também o Código Deontológico da Ordem dos Médicos (CDOM) no artigo 93 (Médicos com responsabilidades directivas) prevê normas que impõem um dever positivo de guarda do segredo:

"1.Os médicos com cargos de direç̧ão em organismos prestadores de cuidados de saúde são responsáveis pela adequação às normas deontológicas dos serviços sob sua tutela, devendo nomeadamente:

a) Estabelecer o controlo necessário para que não seja vulnerável a intimidade e a confidencialidade dos doentes, sob a sua responsabilidade;

b) Tratar as informações a serem transmitidas aos meios de comunicação de um modo adequado e após obtenção do consentimento do doente ou do seu representante legal;

c) Exigir dos seus colaboradores médicos e não-médicos, e ainda dos estudantes das diversas áreas de saúde, a preservação da intimidade e da confidencialidade das informações clínicas, sujeitas a segredo médico."

91 Costa Andrade, Direito Penal Médico, 2004, p. 184-185.

92 Refiro-me à Lei de protecção de dados pessoais (Lei n. ${ }^{\circ}$ 67/98, de 26 de Outubro), especialmente os artigos $14 .^{\circ}$ (Segurança do tratamento), $15 .^{\circ}$ (Medidas especiais de segurança) e 17. ${ }^{\circ}$ (Sigilo profissional) e à Lei de informação genética e informação pessoal de saúde (Lei n. ${ }^{\circ} 12 / 2005$, de 26 de Janeiro), especialmente o art. $4 .^{\circ}$ (Tratamento da informação de saúde). 


\section{Titulares do segredo}

"Portador ou titular do segredo é a pessoa a cuja esfera privada pertencem os factos que o integram." ${ }^{93}$ Pode ser o paciente ou um terceiro.

O paciente detém a posição activa, estando o médico na posição passiva. Assim o sigilo vale nas relações entre o médico e terceiros, não podendo ser oposto pelo clínico ao seu paciente. Donde o paciente tem o direito de conhecer a informação que the respeita, devendo ser facultado o acesso ao processo ou fichas. ${ }^{94}$

\section{Sujeitos do dever: pessoas obrigadas ao sigilo}

Os médicos, outros profissionais de saúde bem como outros profissionais que lidam com os dados médicos estão sujeitos ao dever de segredo profissional.

A lista que apresentamos não é exaustiva, devendo recordar-se que segundo o Código Penal português, qualquer pessoa que tenha tomado conhecimento de segredo alheio em razão do seu estado, ofício, emprego, profissão ou arte está obrigado a sigilo.

\section{i. Médicos}

O Estatuto da Ordem dos Médicos ${ }^{95}$ impõe o segredo profissional como um dos deveres dos médicos (artigo 13. ${ }^{\circ}, \mathrm{c}$ ) EOM), cuja violação pode conduzir à aplicação de uma pena disciplinar. No mesmo sentido, o Código Deontológico da Ordem dos Médicos, prescreve, no artigo 67. o dever de sigilo.

\section{ii. Médicos dentistas}

O Estatuto da Ordem dos Médicos Dentistas ${ }^{96}$ estabelece o dever de segredo no artigo 12. ${ }^{\circ}$, n..$^{\circ}$ 1, al. c). Também o Código Deontológico dos Médicos Dentistas, ${ }^{97}$ que foi aprovado pela Assembleia Geral da Ordem dos Médicos Dentistas, contém normas relativas a esta matéria. ${ }^{98}$

93 Costa Andrade, Direito Penal Médico, 2004, p. 188.

94 Cfr. André Gonçalo Dias Pereira, "Dever de Documentação, Acesso ao Processo Clínico e sua Propriedade. Uma perspectiva europeia”, Revista Portuguesa do Dano Corporal (2006), Ano $\mathrm{XV}, \mathrm{N} .^{\circ} 16$, pp. 9-24

95 Decreto-Lei n. ${ }^{\circ} 282 / 77$, de 5 de Junho.

96 Aprovado pela Lei n. ${ }^{\circ}$ 110/91, de 29 de Agosto, com a redacção da Lei n. ${ }^{\circ}$ 82/98, de 10 de Dezembro, e da Lei n. ${ }^{\circ} 44 / 2003$, de 22 de Agosto.

97 Cfr. http://www.omd.pt

98 Artigo 21. ${ }^{\circ}$ Sigilo Profissional: 1 - O médico dentista é obrigado a guardar sigilo profissional sobre toda a informação relacionada como doente, constante ou não da sua ficha clínica, obtida no exercício da sua profissão. 2 - Os funcionários do médico dentista e todos quantos 


\title{
iii. Enfermeiros
}

\author{
O Estatuto da Ordem dos Enfermeiros (publicado em anexo ao \\ Decreto-Lei n. ${ }^{0} 104$ /98 de 21 de Abril) prevê o dever de sigilo ${ }^{99}$ e o direito \\ à intimidade. ${ }^{100}$
}

\section{iv. Farmacêuticos}

O Estatuto da Ordem dos Farmacêuticos (publicado em anexo ao Decreto-Lei n. ${ }^{\circ} 288 / 2001$, de 10 de Novembro) contém, no capítulo relativo à deontologia profissional, uma a Secção relativa ao sigilo profissional. ${ }^{101}$

com este colaborem no exercício da profissão, estão igualmente sujeitos a sigilo sobre todos os factos de que tenham tomado conhecimento nos respectivos consultórios e no exercício do seu trabalho, desde que esses factos estejam a coberto do sigilo profissional do médico dentista, sendo este deontologicamente responsável pelo respeito do sigilo. 3 - O médico dentista pode prestar informações ao doente ou a terceiro por este indicado. 4 - No caso de intervenção de um terceiro, nos termos do número anterior, o médico dentista pode exigir uma declaração escrita do doente concedendo poderes àquele, para actuar em seu nome. 5 - Qualquer divulgação de matéria sujeita a sigilo profissional, salvo o referido nos números 3 e 4, depende de prévia autorização da Ordem dos Médicos Dentistas. 6 - Não é considerada violação do sigilo profissional a divulgação, para fins académicos, científicos e profissionais, de informação referida no número 1 , desde que sem indicação da identidade do doente. 7 - Não podem fazer prova em juízo, ou fora dele, as declarações prestadas pelo médico dentista com violação do sigilo profissional.

99 Artigo 85. ${ }^{\circ}$ : O enfermeiro, obrigado a guardar segredo profissional sobre o que toma conhecimento no exercício da sua profissão, assume o dever de: a) Considerar confidencial toda a informação acerca do destinatário de cuidados e da família, qualquer que seja a fonte; $b$ ) Partilhar a informação pertinente só com aqueles que estão implicados no plano terapêutico, usando como critérios orientadores o bem-estar, a segurança física, emocional e social do indivíduo e família, assim como os seus direitos; c) Divulgar informação confidencial acerca do indivíduo e família só nas situações previstas na lei, devendo, para tal efeito, recorrer a aconselhamento deontológico e jurídico; d) Manter o anonimato da pessoa sempre que o seu caso for usado em situações de ensino, investigação ou controlo da qualidade de cuidados.

${ }^{100} \mathrm{O}$ direito à intimidade configura lago de distinto do direito ao sigilo. Trata-se de um direito com um conteúdo que se prende mais com o corpo e a integridade física e moral, propriamente dita, e não tanto com a informação. O Estatuto da Ordem dos Enfermeiros dedica-lhe o artigo 86. ${ }^{\circ}$ Do respeito pela intimidade: "Atendendo aos sentimentos de pudor e interioridade inerentes à pessoa, o enfermeiro assume o dever de: $a$ ) Respeitar a intimidade da pessoa e protegê-la de ingerência na sua vida privada e na da sua família; $b$ ) Salvaguardar sempre, no exercício das suas funções e na supervisão das tarefas que delega, a privacidade e a intimidade da pessoa."

101 Artigo 101. ${ }^{\circ}$ (Do sigilo profissional) 1 - Os farmacêuticos são obrigados ao sigilo profissional relativo a todos os factos de que tenham conhecimento no exercício da sua profissão, com excepção das situações previstas na lei. 2 - O dever de sigilo profissional subsiste após a cessação da actividade profissional e ainda quando o farmacêutico altere o seu domicílio profissional. Artigo 102..$^{\circ}$ - (Garantia do sigilo): 1 - Para garantia do sigilo profissional os farmacêuticos, no exercício da sua actividade, devem comportar-se por forma a evitar que terceiros se apercebam das informações respeitantes à situação clínica do doente. 2 - O sigilo profissional obriga os farmacêuticos a absterem-se de mencionar ou comentar factos que possam violar 


\section{v. Terapeutas não convencionais}

A Lei n. ${ }^{\circ}$ 45/2003, de 22 de Agosto - Lei do enquadramento base das terapêuticas não convencionais - prescreve que no âmbito das terapêuticas não convencionais se impõe a obrigação de respeitar a confidencialidade dos dados pessoais e de guardar sigilo. ${ }^{102}$ Consideram-se terapêuticas não convencionais aquelas que partem de uma base filosófica diferente da medicina convencional e aplicam processos específicos de diagnóstico e terapêuticas próprias. Para efeitos de aplicação da presente lei são reconhecidas como terapêuticas não convencionais as praticadas pela acupunctura, homeopatia, osteopatia, naturopatia, fitoterapia e quiropráxia (artigo $3 .^{\circ}$ ).

\section{vi. Técnicos de tratamento de dados}

Segundo o n. ${ }^{\circ} 4$ do artigo $7 .^{\circ}$ da Lei n. $.^{\circ} 67 / 98$, de 26 de Outubro, ${ }^{103}$ os profissionais não médicos que fizerem o tratamento de dados estão também obrigados ao dever de sigilo, podendo incorrer na prática do crime previsto no artigo $47 .^{\circ}$ da mesma Lei..$^{104}$

a privacidade do doente, designadamente os que se relacionam com o respectivo estado de saúde. 3 - A obrigação do sigilo profissional não impede que o farmacêutico tome as precauções necessárias ou participe nas medidas indispensáveis para salvaguarda da vida e saúde das pessoas que coabitem ou privem com o doente.

Artigo $103 .^{\circ}$ - (Recusa de depoimento): Quando notificado como testemunha em processo que envolva um seu doente ou terceiros, o farmacêutico pode recusar-se a prestar declarações que constituam matéria de sigilo profissional, salvo se devidamente autorizado a fazê-lo pelo bastonário.

Artigo $104 .^{\circ}$ - (Constituição de bancos electrónicos de dados): No exercício da sua actividade, o farmacêutico, ao colaborar na constituição de bancos electrónicos de dados, deve respeitar os princípios gerais vigentes.

102 Artigo 10. ${ }^{\circ}$ (Do exercício da actividade) 2: Os profissionais que exercem as terapêuticas não convencionais estão obrigados a manter um registo individualizado de cada utilizador. 3 - $\mathrm{O}$ registo previsto no número anterior deve ser organizado e mantido de forma a respeitar, nos termos da lei, as normas relativas à protecção dos dados pessoais.

Artigo $14 .^{\circ}$ (Confidencialidade): O processo de cada utente, em posse dos profissionais que exercem terapêuticas não convencionais, é confidencial e só pode ser consultado ou cedido mediante autorização expressa do próprio utilizador ou determinação judicial.

103 "O tratamento dos dados referentes à saúde e à vida sexual, incluindo os dados genéticos, é permitido quando for necessário para efeitos de medicina preventiva, de diagnóstico médico, de prestação de cuidados ou tratamentos médicos ou de gestão de serviços de saúde, desde que o tratamento desses dados seja efectuado por um profissional de saúde obrigado a sigilo ou por outra pessoa sujeita igualmente a segredo profissional, seja notificado à CNPD, nos termos do artigo $27 .^{\circ}$, e sejam garantidas medidas adequadas de segurança da informação.

${ }^{104}$ A Lei de Proteç̧ão de Dados Pessoais (Lei n. ${ }^{\circ}$ 67/98, de 26 de Outubro) transpõe para a ordem jurídica portuguesa a Directiva n. ${ }^{\circ}$ 95/46/CE, do Parlamento Europeu e do Conselho, de 24 de Outubro de 1995, relativa à protecção das pessoas singulares no que diz respeito ao tratamento dos dados pessoais e à livre circulação desses dados. 
Por seu turno, o artigo $17 .^{\circ}$ prescreve:

"1. Os responsáveis do tratamento de dados pessoais, bem como as pessoas que, no exercício das suas funções, tenham conhecimento dos dados pessoais tratados, ficam obrigados a sigilo profissional, mesmo após o termo das suas funções.

2. Igual obrigação recai sobre os membros da CNPD, mesmo após o termo do mandato.

3. O disposto nos números anteriores não exclui o dever do fornecimento das informações obrigatórias, nos termos legais, excepto quando constem de ficheiros organizados para fins estatísticos.

4. Os funcionários, agentes ou técnicos que exerçam funções de assessoria à CNPD ou aos seus vogais estão sujeitos à mesma obrigação de sigilo profissional.

\section{vii. Todo o pessoal hospitalar}

Segundo o artigo 57. ${ }^{\circ}$ do Estatuto Hospitalar (Decreto n ${ }^{\circ} 48357$, de 27 de Abril de 1968), ${ }^{105}$ todo o pessoal hospitalar é obrigado a guardar segredo de ofício relativamente aos factos de que tenha conhecimento no exercício das suas funções, nos mesmos termos do pessoal médico.

Deste modo, afigura-se conforme ao direito português a síntese que no plano da bioética é proposta por Hottois e Parizeau, "por extensão, qualquer agente é obrigado ao segredo, mesmo fora de qualquer prescrição especial, pelo simples facto de colaborar numa instituição de saúde ou de serviços sociais. $\mathrm{Na}$ prática, o segredo médico garantirá a não divulgação (ou confidencialidade) de qualquer informação relativa ao perfil sociométrico de uma pessoa." ${ }^{106}$

Costa Andrade concretiza: obrigados a segredo estão os médicos e "igualmente as pessoas que lidam profissionalmente com o paciente: enfermeiros, auxiliares de enfermagem, paramédicos, analistas, farmacêuticos, operadores de radiografia, ecografia, tomografia computorizada, terapeutas, massagistas, técnicos de reabilitação. $\mathrm{O}$ mesmo vale para estudantes ou formandos (ou formadores) quem, nesta qualidade, tenham contacto com o doente ou o processo clínico. (...) o dever de sigilo impende sobre aqueles que, por via da sua profissão, prestam ajuda aos médicos, nomeadamente como secretárias." ${ }^{107}$

Contudo, segundo insigne o Professor de Coimbra, "Diferentemente, já não estarão obrigados a segredo os profissionais, como motoristas, empregados de limpeza, etc. - que, por outra via que não o exercício da profissão, venham a ter conhecimento de segredo." ${ }^{108}$ Não raras vezes, porém, estes profissionais

\footnotetext{
${ }^{105}$ A vigência do Estatuto Hospitalar foi expressamente ressalvada pelo n. ${ }^{\circ} 2$ do artigo $21 .^{\circ}$ do Decreto-Lei n. ${ }^{\circ}$ 19/88, de 21 de Janeiro (aprova a lei de gestão hospitalar), em tudo o que não se encontre regulado neste diploma e respectiva regulamentação.

106 Gilbert Hottois/ Marie-Hélène Parizeu, Dicionário de Bioética, Lisboa, p.328.

${ }^{107}$ Costa Andrade, Direito Penal Médico, 2004, p. 188.

${ }^{108}$ Costa Andrade, Direito Penal Médico, 2004, p. 189.
} 
têm conhecimento de segredos, e só têm conhecimento de segredos, porque estão no exercício daquela profissão. Por isso, e tomando em consideração o elemento gramatical do referido artigo 57. ${ }^{\circ}$ do Estatuto Hospitalar, bem como o elemento teleológico e intencional das normas relativas ao dever de sigilo, sou de parecer que estes profissionais também podem estar obrigados a guardar confidencialidade. Com efeito, estas pessoas têm acesso privilegiado aos segredos dos pacientes por causa da e no exercício da profissão. As exigências de tutela da privacidade e de evitar a devassa da intimidade dos pacientes fazem-se sentir com a mesma (ou maior) intensidade face a estes profissionais como face aos profissionais de saúde stricto senso.

\section{Parte 2. ${ }^{\circ}$ Quebra legítima do sigilo médico - causas de justificação}

Analisemos agora algumas situações que poderão configurar uma causa de justificação da violação do dever de sigilo:

\section{0 consentimento}

Se o interessado consentir na revelação do segredo não há lugar a qualquer ilícito. ${ }^{109} \mathrm{O}$ consentimento está previsto no Código Penal no artigo 38. . .110 No plano do direito civil vigoram os artigos $81 .^{0111}$ e $340 .^{\circ 112}$ do Código Civil.

O consentimento do titular do segredo é livre. Todavia, por vezes a revelação de um segredo de uma pessoa pode implicar a violação da privacidade de outra pessoa.

${ }^{109} \mathrm{O}$ consentimento também é condição necessária para as publicações, quando identificar o paciente. Segudo o artigo $102 .^{\circ}$ do CDOM: “O Médico pode servir-se das suas observações clinicas para as suas publicações, mas deve proceder de modo a que não seja possível a identificação dos doentes, a menos que previamente autorizado a tal."

${ }^{110}$ Artigo $38^{\circ}$ (Consentimento) 1. Além dos casos especialmente previstos na lei, o consentimento exclui a ilicitude do facto quando se referir a interesses jurídicos livremente disponíveis e o facto não ofender os bons costumes. 2. O consentimento pode ser expresso por qualquer meio que traduza uma vontade séria, livre e esclarecida do titular do interesse juridicamente protegido, e pode ser livremente revogado até à execução do facto. 3. O consentimento só é eficaz se for prestado por quem tiver mais de 16 anos e possuir o discernimento necessário para avaliar o seu sentido e alcance no momento em que o presta.

111 Artigo $81^{\circ}$ - Limitação voluntária dos direitos de personalidade 1. Toda a limitação voluntária ao exercício dos direitos de personalidade é nula, se for contrária aos princípios da ordem pública. 2. A limitação voluntária, quando legal, é sempre revogável, ainda que com obrigação de indemnizar os prejuízos causados às legítimas expectativas da outra parte.

112 Artigo $340^{\circ}$ - Consentimento do lesado 1 . O acto lesivo dos direitos de outrem é lícito, desde que este tenha consentido na lesão. 2. O consentimento do lesado não exclui, porém, a ilicitude do acto, quando este for contrário a uma proibição legal ou aos bons costumes. 
$\mathrm{O}$ artigo 88. ${ }^{\circ}$ do CDOM afirma: "Excluem o dever de segredo médico: a) $O$ consentimento do doente ou, em caso de impedimento, do seu representante legal, quando a revelação não prejudique terceiras pessoas com interesse na manutenção do segredo médico."

O consentimento pode ser expresso ou tácito. ${ }^{113}$ Os tribunais alemães têm uma interpretação restritiva do consentimento tácito. Assim, ele abrange os casos de aconselhamento entre colaboradores ou ajudantes do médico e o médico. Mas nem sempre se estão justificados os casos de aconselhamento entre médicos por ocasião de um tratamento. Em Portugal, entendemos que, em regra, será de aplicar o consentimento presumido, como veremos.

\section{0 consentimento presumido}

O consentimento presumido constitui uma causa de justificação autónoma, distinta do consentimento, e encontra-se previsto no artigo $39 .^{\circ}$ do Código Penal $^{114}$ e no artigo 340. ${ }^{\circ}$, n. ${ }^{\circ} 3$ do Código Civil. ${ }^{115}$

O consentimento presumido tem relevo quando o interessado (ou o seu representante legal) não pode pronunciar-se sobre o tratamento, tratando-se de situações especiais.

A comunicação a familiares de uma vítima, que chegou inconsciente, de um acidente. Após a morte, poderá ser a situação de conflitos entre herdeiros por divergências quanto à herança, em que são necessários certos conhecimentos que apenas podem ser obtidos através do médico que tratou o falecido. ${ }^{116}$

No caso de os familiares de uma vítima de erro médico quererem ter acesso ao processo clínico para fundamentar uma acção de responsabilidade, poderá também defender-se o consentimento presumido.

No mesmo sentido, a alínea b) do artigo $88 .^{\circ}$ do CDOM permite ainda a revelação do segredo na medida do que for absolutamente necessário à defesa da dignidade, da honra e dos legítimos interesses do doente. Mas esta quebra do sigilo está sujeita a dois limites: não pode o médico revelar mais do que o necessário e carece de prévia consulta ao Presidente (!) (Bastonário) da Ordem. A norma tem interesse, entre outros casos, para que as pessoas constantes do elenco do artigo $71 .^{\circ}, \mathrm{n}^{\circ}$ 2 do Código Civil possam reagir contra ofensas a bens de personalidade do já

${ }^{113}$ Cfr. Artigo 38. ${ }^{\circ}$ do Código Penal e artigo 217. ${ }^{\circ}$ do Código Civil.

${ }^{114}$ Artigo $39^{\circ}$ (Consentimento presumido) 1. Ao consentimento efectivo é equiparado o consentimento presumido. 2. Há consentimento presumido quando a situação em que o agente actua permitir razoavelmente supor que o titular do interesse juridicamente protegido teria eficazmente consentido no facto, se conhecesse as circunstâncias em que este é praticado.

115 Artigo $340^{\circ}$ - Consentimento do lesado 3. Tem-se por consentida a lesão, quando esta se deu no interesse do lesado e de acordo com a sua vontade presumível.

${ }^{116}$ Peter Hünerfeld, Esfera Privada e Segredo, 2004, p. 201. 
falecido, ou quando os familiares queiram ter acesso aos ficheiros clínicos com o objectivo de responsabilizar o médico. "A vontade hipotética de um cidadão comum, reconstruída em termos objectivos, com apelo ao princípio da boa fé, vai certamente no sentido de facultar aos familiares o acesso à informação necessária para uma eventual responsabilização do médico que o assistiu sem sucesso."117

No âmbito do consentimento presumido podemos influir o que a doutrina chama de segredo partilhado. O interesse do doente, fundamento da obrigação do segredo médico, justifica que a obrigação possa circular, na medida do necessário, entre os diferentes profissionais que intervêm no tratamento.

Assim acontece desde logo, quando, de acordo com o dever de respeito por qualificações e competência, o médico assistente "quando lhe pareça indicado, deve pedir a colaboração de outro médico ou indicar ao doente um colega que julgue mais qualificado" (art. 36. ${ }^{\circ}$, n. $^{\circ} 3$ do CDOM).

Estando em causa exames e terapêuticas especializados, o artigo $138^{\circ}$ do novo CDOM impõe o dever de recomendação nos seguintes termos:

"1. Quando o doente necessitar de exame ou terapêutica especializados que o médico assistente considere ultrapassarem a sua competência deverá este, com o acordo do doente e com a celeridade possível, sugerir-lhe o colega que julgue competente para o caso, devendo pôr este ao corrente dos dados úteis.

2. A fim de assegurar a continuidade dos cuidados médicos, o médico consultor deve reenviar, logo que possível, o doente ao médico assistente, enviando, também, os resultados e as conclusões do seu exame."

No caso de hospitalização, prescreve o art. $140^{\circ}$ :

"1. O médico assistente que envie um doente a um hospital deve transmitir aos respectivos serviços médicos os elementos necessários à continuidade dos cuidados clínicos.

2. Os médicos responsáveis pelo doente no decurso do seu internamento hospitalar devem prestar ao médico assistente todas as informações úteis acerca do respectivo caso clínico, através de relatório escrito."

\section{Transferência de fichas}

Segundo a doutrina alemã, o consentimento tácito não abrange os casos de o médico que deixa de exercer e transmite com o seu consultório os ficheiros dos pacientes a outro médico. ${ }^{118}$ Podemos estar perante casos de violação do dever de sigilo.

${ }^{117}$ Luís Vasconcelos Abreu, O segredo médico no direito português vigente, 2005, p. 278.

${ }^{118}$ Adolf Laufs, Arztrecht, p. 247, apud, Peter Hünerfeld, Esfera Privada e Segredo, 2004, p. 200. 
Contudo, o artigo $103 .{ }^{\circ}$, n. $^{\circ} 1^{119}$ do CDOM parece apontar para uma situação de consentimento presumido dos pacientes, salvaguardando a possibilidade de os pacientes se recusarem a essa transmissão.

Estamos assim perante duas perspectivas antagónicas. Para alguns (os tribunais alemães) os pacientes deverão dar o consentimento expresso para que haja transmissão das fichas do doente; segundo o CDOM haverá uma situação de consentimento presumido.

Seria mais conforme ao princípio da proporcionalidade (artigo $18 .^{\circ} \mathrm{CRP}$ ), conjugado com a protecção constitucional da intimidade da vida privada (artigo 26. ${ }^{\circ} \mathrm{CRP}$ ) exigir que o médico notifique todos os doentes notificandoos de que vai transmitir o consultório e solicitando-lhes autorização expressa (consentimento expresso) para transmitir os seus processos. Contudo, esta burocratização excessiva poderia lesar o bem jurídico "saúde" dos próprios pacientes. Com efeito, o processo clínico tem um valor precioso para a prática clínica, permitindo um melhor diagnóstico e um tratamento mais adequado. Donde, as eventuais exigências de notificação ao paciente e de autorização expressa do mesmo poderiam conduzir a uma indesejável destruição do processo. Assim sendo, parece-me que a norma do CDOM pode considerar-se válida, ${ }^{120}$ mas deve enquadrar-se no âmbito do consentimento presumido $\mathrm{e}$ não do consentimento tácito.

\section{0 direito de necessidade}

O direito de necessidade é uma cláusula de exclusão da ilicitude tradicional, prevista quer no Código Penal (artigo 34. ${ }^{\circ}$ ), ${ }^{121}$ quer no Código Civil (artigo $\left.339 .^{\circ}\right) .{ }^{122}$

119 Art. 103. ${ }^{\circ}$ (Destino dos registos em caso de transmissão de consultório) 1. Quando o Médico cesse a sua actividade profissional, as suas fichas devem ser transmitidas ao Médico que lhe suceda, salvaguardada a vontade dos doentes interessados e garantido o segredo profissional.

120 No mesmo sentido, referindo-se aos ficheiros de pessoas falecidas, Luís Vasconcelos Abreu, O segredo médico no direito português vigente, 2005, p. 284.

${ }^{121}$ Artigo $34 .^{\circ}$ Direito de necessidade - Não é ilícito o facto praticado como meio adequado para afastar um perigo actual que ameace interesses juridicamente protegidos do agente ou de terceiro, quando se verificarem os seguintes requisitos: a) Não ter sido voluntariamente criada pelo agente a situação de perigo, salvo tratando -se de proteger o interesse de terceiro; b) Haver sensível superioridade do interesse a salvaguardar relativamente ao interesse sacrificado; e c) Ser razoável impor ao lesado o sacrifício do seu interesse em atenção à natureza ou ao valor do interesse ameaçado.

122 Artigo 339. ${ }^{\circ}$ (Estado de necessidade) - 1. É lícita a acção daquele que destruir ou danificar coisa alheia com o fim de remover perigo actual de um dano manifestamente superior, quer do agente, quer de terceiro. 2. O autor da destruição ou do dano é, todavia, obrigado a indemnizar o lesado pelo prejuízo sofrido, se o perigo for provocado por sua culpa exclusiva; 
A doutrina ${ }^{123}$ entende que se pode aplicar o direito de necessidade em alguns grupos de casos

i) Relativos à administração da justiça penal:124

Perigo fundamentado de repetição de prática de ilícitos penais graves;

Quando seja necessário para evitar a condenação de um inocente;

ii) Relativos à protecção de interesses de terceiros:

Informação a um familiar que coabite com o paciente dos perigos de infecção de uma doença grave, nos estritos termos que veremos de seguida;

Médico que informa as autoridades de trânsito sobre a doença grave e permanente de que alguém é portador, porque devido a ela o doente constitui um perigo real para a segurança rodoviária, tornando-se imperativo a cassação da licença de condução;

iii) Ou mesmo para defesa de interesses do próprio médico:

A salvaguarda dos legítimos interesses do médico também pode justificar a quebra do sigilo. O médico poderá, após consulta ao Presidente da Ordem, quebrar o sigilo a que se encontra vinculado nos casos em que isso seja absolutamente necessário à defesa da sua dignidade, da sua honra e dos seus legítimos interesses (art. 88. ${ }^{\circ}$, al. b) do CDOM). Um exemplo será no âmbito de um processo de responsabilidade médica movido pelo paciente contra o médico, este vir a juízo defender-se. Assim, a quebra do sigilo é legítima para afastar a imputação desonrosa feita ao médico.

\section{i. Comunicação a terceiros de que o paciente sofre de doença trans- missível grave}

Tem sido maioritariamente aceite a licitude, através do direito de necessidade, da revelação de segredo relativo a doença grave e transmissível para a salvaguarda da vida e da saúde de terceiros, nomeadamente no caso da SIDA.

É essa a opinião do Conselho Nacional de Ética para as Ciências da Vida, que se que deu o seguinte parecer (Parecer 32/CNECV/2000):

"1. A médica assistente deve continuar a envidar todos os esforços para rapidamente persuadir o seu doente da obrigação grave que sobre ele impende de comunicar à sua mulher a seropositividade que apresenta e os riscos da sua transmissão. Se necessário, deverá mesmo explicar-lhe que, nestas circunstâncias específicas de perigo próximo para a saúde e vida de terceiros, as normas

em qualquer caso, o tribunal pode fixar indemnização equitativa e condenar nela não só o agente, como aqueles que tiraram proveito do acto ou contribuíram para o estado de necessidade."

${ }^{123}$ Recorremos a exemplos de Peter Hünerfeld, Esfera Privada e Segredo, 2004, p.204 e de Costa Andrade, Comentário, I, pp. 798-801.

${ }^{124}$ Cfr. o que diremos sobre o Processo Penal. 
éticas de respeito pela legitimidade e pela vida desses terceiros justificam a comunicação em causa.

2. Se, mesmo assim, não conseguir persuadir o seu doente, a médica deve informá-lo que irá cumprir a sua obrigação de comunicar à mulher a seropositividade do seu marido e os riscos da sua transmissão, o que não pressupõe, neste caso, quebra do sigilo médico.

3. Esta comunicação é indispensável para que a mulher do doente possa fazer os testes de diagnóstico e iniciar tratamento, caso já tenha sido infectada."

Costa Andrade entende que é hoje praticamente consensual a licitude (ex $v i$ direito de necessidade) da revelação do segredo relativo a doença grave e transmissível com vista à salvaguarda da vida e da saúde de terceiros. O médico pode revelar aos familiares que alguém é portador da doença sexualmente transmissível caso ele não se disponha a fazê-lo. Reconhece-se ao médico o direito de necessidade de informar os familiares do portador da doença que se recusa a fazê-lo bem como outros médicos ou profissionais de saúde que vão lidar com ele. ${ }^{125}$

"Já se questiona inclusivamente, se para além do direito (de informar) não haverá casos em que o médico tem o dever de o fazer. Por exemplo, no caso de um casal em que o médico é simultaneamente médico de ambos, tendo portanto o dever de informar um dos seus consulentes sobre os riscos de saúde em que incorre, mesmo violando outro dever, o de manter sigilo sobre o estado clínico de outro dos seus doentes."126

Se afirmarmos a existência de um dever de informar, ${ }^{127}$ estando o médico na posição de garante face ao cônjuge lesado, pode incorrer em responsabilidade criminal por prática de homicídio ou ofensas à integridade física por omissão (art. $10^{\circ} \mathrm{CP}$ - que regula a omissão impura).

Outros autores, como o francês Olivier Dupuy, ${ }^{128}$ defendem que o médico está obrigado ao dever de sigilo, mesmo perante o cônjuge, por várias razões. Desde logo, tratar-se-ia de uma violação do artigo do Código Penal francês que incrimina a violação do sigilo profissional e o mesmo Código não prevê uma excepção a essa regra da confidencialidade. Para além disso, uma prática de denúncia sistemática dissuadiria as pessoas de realizar os testes de

125 Costa Andrade, Comentário, I, p. 797-798.

126 Jornal Tempo Medicina, de 13 de Maio de 2002, reproduzindo palavras de Costa Andrade numa Conferência no Hospital de São José.

${ }^{127}$ Nesse sentido, Peter Hünerfeld, Esfera Privada e Segredo, 2004, p.212. Afirma este autor alemão: "deve-se, em princípio, considerar que o médico está obrigado a informar o parceiro em perigo, quando ambos os parceiros se encontram em tratamento no mesmo médico e este for o único meio fiável que permita informar o parceiro da existência de uma infecção VIH.

${ }^{128}$ Olivier Dupuy, L’information médicale, 2002, p. 60. 
despistagem do vírus considerando que a sua família iria ficar a conhecer o seu estado de saúde. Pode-se pensar que a introdução de um direito à revelação induziria paradoxalmente ao desenvolvimento de uma desresponsabilização dos indivíduos contaminados. O paciente renunciaria à despistagem tendo em conta o risco de marginalização social e familiar involuntária. Acresce que o médico teria muita dificuldade na identificação da pessoa a informar e a capacidade de revelação que se concedesse aos médicos não permitiria garantir uma difusão perfeita da informação.

Isto sem embargo de se poder impor um controlo anonimizado para efeitos estatísticos e epidemiológicos.

Concordo que, em situações limite, o médico pode revelar essa informação ao cônjuge, parceiro sexual ou outro terceiro que esteja perante um perigo iminente de contágio. ${ }^{129}$ Já a afirmação de que o médico tem um dever de informar, cujo não cumprimento poderia levar à condenação por homicídio ou ofensa à integridade física grave, parece-me uma subversão do sistema de segredo médico e da relação médico - paciente. Estaríamos a afectar de modo radical essa relação que tem na sua base, necessariamente, a confiança. Como afirmam Mason \& McCall Smith:

"The crucial dilemma here is whether relaxation of the confidentiality rule would lead to failure to seek advice and treatment and hence to the spread of the disease, or whether the imposition of absolute secrecy improperly denies others the opportunity to avoid the risk of exposure to infection." ${ }^{130}$

Por isso, a quebra da confidencialidade deve ser excepcional. "Any departure from the strictest anonymity in respect of HIV-related information must be subject to intense scrutiny." 131

Contudo, o Código Deontológico da Ordem dos Médicos, na sua versão de Novembro de 2008 trouxe relevantes novidades nesta matéria. Aí se afirma, no artigo $89 .^{\circ}$ que:

\footnotetext{
${ }^{129}$ No mesmo sentido pronunciou-se a Associação Médica canadiana, afirmando que o médico, em último recurso, podia efectivamente divulgar essa doença ao cônjuge. Cfr. Gilbert Hottois/ Marie-Hélène Parizeu, Dicionário de Bioética, Lisboa, p.333.

Na doutrina portuguesa, entre outros, vide Carla Amado Gomes, Defesa da Saúde Pública vs. Liberdade individual, Casos da vida de um médico de saúde pública, Lisboa, AAFDL, 1999, 32/33; João Vaz Rodrigues, O Consentimento Informado para o Acto Médico no Ordenamento Jurídico Português (Elementos para o Estudo da Manifestação da Vontade do Paciente), Publicações do Centro de Direito Biomédico, 3, Coimbra, Coimbra Editora, 2001, p. 248-252.

${ }^{130}$ Mason \& McCall Smith, Law and Medical Ethics ${ }^{5}$, London, Edimburgh, Dublin, Butterworths, 1999, p. 198.

${ }^{131}$ Mason \& McCall Smith, Law and Medical Ethics 5 , p. 199.
} 
“2. Sendo a preservação da vida o valor fundamental, deverá o médico, em circunstância em que um doente tenha um comportamento que traga um risco real e significativo para a vida de outra pessoa, tentar persuadi-lo a modificar este comportamento, nomeadamente declarando que irá revelar a sua situação às pessoas interessadas. Se o doente não modificar o seu comportamento, apesar de advertido, o médico deve informar as pessoas em risco, caso as conheça, após comunicar ao doente que o vai fazer."

Ora, o Código vem pois estabelecer um dever de informar as pessoas em risco. A Ordem dos Médicos opta, pois, pela consagração da chamada doutrina Tarasoff. A "Tarasoff rule" foi aplicada pelo Supremo Tribunal da Califórnia no caso Tarasoff v. Regents of the University of California (17 Cal.3d 425 [1976]) e em 1985 plasmada em lei nesse mesmo Estado americano. Segundo essa lei californiana, um psicoterapeuta tem o dever de proteger ou avisar uma terceira pessoa se o terapeuta acreditar ou prever que o paciente representa um perigo sério de ofensa grave à integridade física de uma vítima razoavelmente identificável. ${ }^{132}$

A consagração desta norma na parte final do n. 2 do artigo $89 .^{\circ}$ do Código Deontológico terá relevância meramente interna, em processos disciplinares, ou pode ter relevância externa, designadamente num processo criminal?

Tendo em conta que se trata de um Código afirma claramente a diferença entre a Deontologia e o Direito/Lei, considerando ainda que foi publicado sob a forma de um Regulamento da Ordem dos Médicos, publicado na II. ${ }^{a}$ Série do Diário da República, e que consequentemente não seguiu os exigentes trâmites de publicidade e controlo a que se submete a lei em sentido formal, temos que concluir que não deve um tribunal sentir-se vinculado a punir designadamente pela prática do crime de homicídio praticado por omissão - o médico que não cumpra esse "dever" (deontológico) de "informar as pessoas em risco, caso as conheça, após comunicar ao doente que o vai fazer."

Esse passo incriminatório poderia ferir gravemente a relação médicopaciente que mantém no mandamento hipocrático do segredo médico um pilar fundamental.

\section{A cobrança (judicial ou extrajudicial) de honorários}

Esta polémica questão está regulada no Artigo 90. (Manutenção do segredo em cobrança de honorários) do CDOM:

${ }^{132}$ Apesar de a lei pretender restringir o alcance desse dever de violação do sigilo profissional, em 2004 o Tribunal de Apelação da Califórnia (nas decisões Ewing v. Goldstein (120 Cal. App. 4th 807 [2004]) e Ewing v. Northridge Hospital Medical Center (120 Cal. App. 4th 1289 [2004]) voltou a ampliar esse dever. 
"Na cobrança judicial ou extrajudicial de honorários, o Médico não pode quebrar o segredo profissional a que está vinculado, salvo o disposto no artigo $88^{\circ}$, a) e b)."

Esta ressalva da parte final deste artigo, deve ser interpretado no sentido de permitir a quebra de segredo para a cobrança de honorários. Se o médico deve obtiver um parecer favorável do Presidente ${ }^{133}$ da Ordem dos Médicos, pode quebrar, dentro do princípio da proporcionalidade, o sigilo médico para cobrar honorários. ${ }^{134}$ Aliás, se assim não fosse, não se descortina como poderia o médico fazer valer o seu direito, aliás, constitucionalmente tutelado (art. 22. ${ }^{\circ}$ CRP). ${ }^{135}$ No mesmo sentido, Peter Hünerfeld aceita a divulgação de segredo necessária à sua autodefesa, e o mesmo vale no que se refere à defesa dos seus direitos no âmbito de um litígio referente ao pagamento de honorários. ${ }^{136}$

Este caso não configura um verdadeiro estado de necessidade, já que os interesses patrimoniais do médico não se afiguram (pelo menos em abstracto) sensivelmente superiores ao interesse pessoal da privacidade do paciente. Tecnicamente, Costa Andrade entende estarmos aqui perante uma situação de quase-legítima-defesa. ${ }^{137}$ Laufs e Uhlenbruck, por seu turno, preferem enquadrar este caso na causa de justificação "prossecução de interesses legítimos." 138

\section{Autorizações legais}

O segredo médico não é absoluto. O interesse social, que exige o segredo em geral, requer a sua revelação em determinados casos, de que são exemplos, as epidemias. As leis de Saúde pública obrigam a declarar à autoridade sanitária certas doenças transmissíveis, estabelecem a lista dessas doenças bem como as formas e condições da sua declaração. ${ }^{139}$ Nesse sentido, afirma o CDOM, no artigo 88.': "Excluem o dever de segredo médico: c) O que revele um nascimento ou um óbito; d) As doenças de declaração obrigatória."

${ }^{133}$ O Código quer referir o Bastonário da OM mas mantém, por lapso, a versão do Estatuto da Ordem dos Médicos de 1956.

${ }^{134}$ Discordamos pois da interpretação do Luís Vasconcelos Abreu que entende que a cobrança de honorários nunca justifica a quebra de sigilo. Este era o regime imposto pelo antigo artigo 92. ${ }^{\circ}$ do Estatuto da Ordem dos Médicos de 1956.

${ }^{135}$ Sobre esta matéria, criticando a exigência de um parecer prévio e vinculativo do Bastonário da Ordem dos Médicos, vide André Gonçalo Dias Pereira, "Sigilo Médico! E o do Advogado?”, Revista Portuguesa do Dano Corporal (2005), Ano XIV, N. . 15, pp. 119-132.

${ }^{136}$ Peter Hünerfeld, Esfera Privada e Segredo, p.204

${ }_{137}$ Costa Andrade, Comentário, I, p. 800.

${ }^{138}$ Laufs/ Uhlenbruck, p. 559

${ }^{139}$ Cfr. Gilbert Hottois/ Marie-Hélène Parizeu, Dicionário de Bioética, Lisboa, p.331. 


\section{i. Saúde pública. As doenças de declaração obrigatória}

Com efeito, a protecção da saúde pública constitui uma típica excepção à regra da confidencialidade. A Lei n. ${ }^{\circ}$ 81/2009, de 21 de Agosto, institui um sistema de vigilância em saúde pública, que identifica situações de risco, recolhe, actualiza, analisa e divulga os dados relativos a doenças transmissíveis e outros riscos em saúde pública, bem como prepara planos de contingência face a situações de emergência ou tão graves como de calamidade pública.

Os deveres de participação constam também do Decreto-Lei n. ${ }^{\circ}$ 89/77, de 8 de Março, posteriormente alterado pelo Decreto-Lei n. ${ }^{\circ}$ 229/94 de 13 de Setembro, que regulamenta o afastamento temporário da frequência escolar e demais actividades desenvolvidas nos estabelecimentos de ensino dos alunos, pessoal docente, administrativo e auxiliar quando atingidos por doenças transmissíveis.

Na Alemanha, vigora, desde 1 de Janeiro de 2001, a nova lei de protecção contra a transmissão, por meio de infecção, de doenças graves (Infektionsschtzgesetz). No caso de determinadas doenças infecciosas e de doenças provocadas por determinados micróbios patogénicos a lei impõe o dever de comunicação à autoridade de saúde nominal, ou seja, o médico deve quebrar o sigilo com vista a proteger a saúde pública. Este exemplo é de especial interesse em regiões que podem ser vítimas de uma epidemia de SARS ou de gripe das aves. ${ }^{140}$

A comunicação nominal não deve ser usada no caso do VIH. Na Alemanha existe apenas o dever de comunicação não nominal. Isto é, não se revela o nome do portador de VIH. ${ }^{141,142}$

${ }^{140}$ Cfr. George J. Annas, Terrorismo, Tortura e outras epidemias pós 11 de Setembro, Sub Judice - Justiça e Sociedade, Março de 2007, 38, pp. 15-32 e Wendy K. Mariner, O papel do direito no controlo de epidemias: o exemplo da TB, VIH e da SARS, Sub Judice - Justiça e Sociedade, Março de 2007, 38, 33-64.

${ }^{141}$ Sobre os problemas jurídicos colocados pelo VIH/SIDA e suas implicações no âmbito do direito ao sigilo médico e do direito à não discriminação, vejam-se as seguintes obras: André Gonçalo Dias Pereira, "Os Direitos dos Utentes Seropositivos nos Lares de Terceira Idade", Lex Medicinae - Revista Portuguesa de Direito da Saúde, N. ${ }^{\circ}$ 5, (2006), 145-158; Idem, "Discriminação de um trabalhador portador de VIH/SIDA: estudo de caso", Lex Medicinae - Revista Portuguesa de Direito da Saúde, N. ${ }^{\circ}$ 6, 2006, pp. 121-135; IDEM, "Cirurgião Seropositivo: do Pânico ao Direito", Lex Medicinae - Revista Portuguesa de Direito da Saúde, Ano 4, n. o8, 2007, 97-114; Idem, Congresso Virtual AIDS.net: "Sigilo Médico e SIDA: breves apontamentos" (http://www. aidscongress.net/pdf/213.pdf ; Idem, EU-CHINA Human Rights Network: "HIV/AIDS - Legal aspects". http://www.nuigalway.ie/sites/eu-china-humanrights/seminars/ns0404.php; Idem, EUCHINA Human Rights Network: "Stigma and discrimination against persons living with HIV/ AIDS in the workplace, in health care facilities, in accessing treatment, and in society: Topics for discussion, http://www.nuigalway.ie/sites/eu-china-humanrights/seminars/ds0411.php

${ }^{142}$ A Recomendação R (89) 15 do Comité de Ministros do Conselho da Europa aos Estados Parte sobre os assuntos éticos da infecção VIH nos serviços de saúde e nos equipamentos sociais impõe aos Estados o dever de lutar contra a discriminação dos portadores de HIV/SIDA na 


\section{ii. Obrigação de denúncia de crimes}

Em Portugal não existe uma obrigação geral de denúncia de crimes graves. O Código de Processo penal apenas impõe (Artigo 242. ${ }^{\circ}$ ) o dever de denúncia obrigatória para as entidades policiais, quanto a todos os crimes de que tomarem conhecimento; e para os funcionários, na acepção do artigo $386 .^{\circ}$ do Código Penal, quanto a crimes de que tomarem conhecimento no exercício das suas funções e por causa delas.

Em regra, "os valores ou interesses encabeçados pelo processo penal (identificação e perseguição dos criminosos e repressão dos crimes passados), a saber a eficácia da justiça penal, não justificam, só por si, a revelação do segredo. ${ }^{143}$ Assim, o dever de segredo prevalece sobre o dever de denúncia obrigatória (art. 242. ${ }^{\circ}$ CPP). Só se admitindo excepções ao princípio nos casos extremados de crimes mais graves que ponham em causa a paz jurídica ou haja o perigo fundado de novas infracções, ${ }^{144}$ como será o caso, por exemplo, da violência e abuso de menores e, nos casos mais graves de violência doméstica.

Na Alemanha, existe uma obrigação geral de denúncia de crimes, nos termos dos §§ 138 e 139 do Código Penal alemão. Essa obrigação pode abranger a denúncia às autoridades ou o aviso da possível vítima. No caso de médicos, o dever de denúncia de crimes está muito limitado. Todavia ainda abrange os casos de assassínio ou homicídio e outros crimes graves; o médico deve denunciar os factos ilícitos dos quais tenha tido conhecimento por ocasião da sua actividade, com a condição de que o médico tenha tentado seriamente (embora sem êxito) desviar o agente da prática do crime ou tenha tentado impedir a verificação do resultado.

\section{iii. O regime dos acidentes de trabalho}

A Lei n. ${ }^{\circ}$ 98/2009 de 4 de Setembro regulamenta o regime de reparação de acidentes de trabalho e de doenças profissionais, incluindo a reabilitação

relação laboral, colocando especial ênfase nos deveres de confidencialidade e de não discriminação dos portadores de VIH que recaem sobre os profissionais de saúde da medicina do trabalho.

Esta mesma linha de raciocínio é seguida pelos tribunais da União Europeia. Vejam-se o Acórdão do Tribunal de Primeira Instância de 18 de Setembro de 1992 (in Colectânea de Jurisprudência do Tribunal de Justiça e do tribunal de Primeira Instância, 1992-9, p. II 2197") e o Acórdão do Tribunal Europeu de Justiça de 5 de Outubro de 1994 (Colectânea de Jurisprudência do Tribunal de Justiça e do Tribunal de Primeira Instância, 1994-10, I-4781 a 4793). Cfr. António Colaço, "O infectado de VIH: a aguardar cidadania plena em sede laboral (Resenha jurisprudencial; pistas para uma solução jurídica), Revista do Ministério Público, Janeiro-Março 2003, n. ${ }^{\circ}$ 93, pp. 101-112.

143 Costa Andrade, Comentário, I, 799.

${ }^{144}$ Costa Andrade, Comentário, I, 799. 
e reintegração profissionais, nos termos do artigo 284 do código do trabalho. Afirma o seu artigo 37. ${ }^{\circ}$ (Requisição pelo tribunal):

"A entidade responsável, os estabelecimentos hospitalares, os serviços competentes da segurança social e os médicos são obrigados a fornecer aos tribunais do trabalho todos os esclarecimentos e documentos que lhes sejam requisitados relativamente a observações e tratamentos feitos a sinistrados ou, por qualquer outro modo, relacionados com o acidente."

\section{iv. Os poderes da Inspecção-Geral das Actividades em Saúde}

O Decreto-Lei n. ${ }^{\circ}$ 275/2007, de 30 de Julho, regula a Inspecção -Geral das Actividades em Saúde. Trata-se de um serviço central da administração directa do Estado, dotado de autonomia administrativa. Como se escreve no preâmbulo: “A Inspecção -Geral das Actividades em Saúde, herdeira da Inspecção -Geral da Saúde quanto à maioria das suas atribuições e competências, recebe nova designação e, mantendo a sua vocação de instância de controlo do orçamento da saúde e do funcionamento das instituições e serviços, passa agora a abranger também os serviços centrais do Ministério e vê alargado o seu âmbito de actuação às entidades privadas.

Como garantia do exercício da actividade de inspecção, o artigo $5 .^{\circ}$ prescreve:

"Sem prejuízo das garantias gerais do exercício da actividade de inspecção, os dirigentes e pessoal de inspecção da IGAS podem requisitar, para consulta ou junção aos autos, processos ou documentos, designadamente os existentes nos arquivos clínicos das instituições e serviços."

\section{0 sigilo médico e o processo penal: 0 princípio da prevalência do interesse pre- ponderante}

O artigo 519. ${ }^{\circ}$, n. ${ }^{\circ} 4$ do Código de Processo Civil remete o levantamento do segredo profissional para o disposto no processo penal. Este Código regula regime de quebra do sigilo no artigo $135 .^{\circ}$ do CPP que estabelece o princípio da prevalência do interesse preponderante.

Os valores da administração da justiça e, em particular, os interesses encabeçados pelo processo penal não justificam, só por si, a quebra do sigilo médico, ${ }^{145}$ pelo que o médico tem o direito/ dever de recusa de prestar depoimento. ${ }^{146}$

145 Costa Andrade, Comentário, I, p. 799.

146 Sobre esta matéria vide as interessantes anotações de Helena Moniz, "Segredo Médico, Acórdão da Relação de Coimbra de 5 de Julho de 2000 e Acórdão da Relação do Porto de 20 


\section{Assim reza o Artigo $135 .^{\circ}$ Segredo profissional: ${ }^{147}$}

1. Os ministros de religião ou confissão religiosa e os advogados, médicos, jornalistas, membros de instituições de crédito e as demais pessoas a quem a lei permitir ou impuser que guardem segredo podem escusar-se a depor sobre os factos por ele abrangidos.

Esta norma não deve interpretar-se como dando uma faculdade ou o direito de escolha a estas pessoas, nomeadamente aos médicos, de se escusar a depor sobre factos abrangidos pelo segredo. ${ }^{148}$ Contudo, quando o paciente desonera o médico do seu dever de reserva, consentindo na revelação do segredo, este não pode mais recusar o depoimento.

Segundo o artigo $135 .^{\circ}$, n. ${ }^{\circ} 2$ e 3 do Código de Processo Penal, no caso de existirem dúvidas quanto à recusa do médico de prestar depoimento, a decisão é remetida ao tribunal superior para apreciação. A Ordem dos Médicos deverá ser chamada a dar parecer sobre a situação. Donde não existe um direito absoluto ao silêncio por parte destes obrigados ao segredo.

Perante a recusa do médico, ordena o n. ${ }^{\circ}$ :

"Havendo dúvidas fundadas sobre a legitimidade da escusa, a autoridade judiciária perante a qual o incidente se tiver suscitado procede às averiguações necessárias. Se, após estas, concluir pela ilegitimidade da escusa, ordena, ou requer ao tribunal que ordene, a prestação do depoimento."

A decisão final sobre se o médico deve ou não depor sobre factos abrangidos pelo sigilo cabe a um tribunal, a saber: "o tribunal superior àquele onde o incidente tiver sido suscitado, ou, no caso de o incidente ter sido suscitado perante o Supremo Tribunal de Justiça, o pleno das secções criminais."

Os critérios da decisão do tribunal foram densificados na Reforma de 2007, no n. ${ }^{\circ} 3$, nos seguintes termos:

o tribunal "pode decidir da prestação de testemunho com quebra do segredo profissional sempre que esta se mostre justificada, segundo o princípio da prevalência do interesse preponderante, nomeadamente tendo em conta a imprescindibilidade do depoimento para a descoberta da verdade, a gravidade do crime e a necessidade de protecção de bens jurídicos."

Trata-se, por um lado, de uma lista de critérios não taxativos: veja-se a utilização do advérbio "nomeadamente"; e por outro lado, não automáticos,

de Setembro de 2000," Revista Portuguesa de Ciência Criminal, Ano 10, Fasc. 4. ${ }^{\circ}$, Outubro Dezembro, 2000, 629-642.

${ }_{147}$ Segundo a Lei n. ${ }^{\circ}$ 48/2007, de 29 de Agosto.

${ }^{148}$ Costa Andrade, Comentário, I, p. 796. 
como resulta da expressão "tendo em conta". Compete ao tribunal uma ponderação concreta, caso a caso, dos interesses em conflito.

Por outro lado ainda, antes de tomar a decisão o tribunal deve consultar a Ordem dos Médicos, como impõe o n. ${ }^{\circ}$ 4:

4. Nos casos previstos nos n. ${ }^{o s} 2$ e 3 , a decisão da autoridade judiciária ou do tribunal é tomada ouvido o organismo representativo da profissão relacionada com o segredo profissional em causa, nos termos e com os efeitos previstos na legislação que a esse organismo seja aplicável.

Assim, concluímos que o médico não tem um direito absoluto a não depor em juízo, cabendo a decisão final ao tribunal competente.

Só os obrigados a segredo religioso têm um direito absoluto de não depor em tribunal, como resulta do n. 5 do art. 135 . $^{\circ} \mathrm{CPP}$, o que pode constituir uma violação do princípio da igualdade perante a lei e da liberdade de consciência (artigo 41. ${ }^{\circ}$ da CRP), na medida em que quem, por razões de consciência, entenda confessar factos da sua esfera íntima não a um ministro de religião, mas a um profissional qualificado, designadamente a um psicólogo, um médico ou um advogado, não goza da mesma garantia de não revelação de segredos em tribunal.

$\mathrm{O}$ direito de recusa de prestar depoimento permite que o médico esteja autorizado a não prestar depoimento relativamente àquilo que lhe é confiado devido à sua qualidade de médico ou de que ele teve conhecimento por ocasião do exercício da sua profissão. Nesse sentido, dispõe - num sentido concordante com o Código de Processo Penal - o art. 91. ${ }^{\circ}$ do CDOM (Intimação judicial):

1. O médico que nessa qualidade seja devidamente intimado como testemunha ou perito, deverá comparecer no tribunal, mas não poderá prestar declarações ou produzir depoimento sobre matéria de segredo profissional.

2. Quando um Médico alegue segredo profissional para não prestar esclarecimentos pedidos por entidade pública, pode solicitar à Ordem dos Médicos declaração que ateste a natureza inviolável do segredo em causa.

Por outro lado, há normas especiais de protecção do processo clínico face a apreensões para fins de investigação criminal. Assim, o artigo $180{ }^{\circ}$ relativo à apreensão em escritório de advogado ou em consultório médico manda aplicar as regras da busca domiciliária (art. 180. ${ }^{\circ}$, n. ${ }^{\circ} 1$ e art. $177 .^{\circ}$, n. ${ }^{\circ} 5$ e 6), a saber:

“5. Tratando -se de busca em escritório de advogado ou em consultório médico, ela é, sob pena de nulidade, presidida pessoalmente pelo juiz, o qual avisa previamente o presidente do conselho local da Ordem dos Advogados ou da Ordem dos Médicos, para que o mesmo, ou um seu delegado, possa estar presente. 
6. Tratando-se de busca em estabelecimento oficial de saúde, o aviso a que se refere o número anterior é feito ao presidente do conselho directivo ou de gestão do estabelecimento ou a quem legalmente o substituir."

$\mathrm{O}$ n. ${ }^{\circ}$ do art. $180 .^{\circ}$ vem reforçar o carácter sigiloso, ameaçando com a sanção de nulidade a "apreensão de documentos abrangidos pelo segredo profissional, ou abrangidos por segredo profissional médico, salvo se eles mesmo constituírem objecto ou elemento de um crime."

Finalmente, o n. ${ }^{\circ} 3$ do art. $180 .^{\circ}$ (que remete para o n. ${ }^{\circ} 3$ do art. 179..$\left.^{\circ}\right)$ dispõe:

"o juiz que tiver autorizado ou ordenado a diligência é a primeira pessoa a tomar conhecimento do conteúdo da correspondência apreendida. Se a considerar relevante para a prova, fá-la juntar ao processo; caso contrário, restitui-a a quem de direito, não podendo ela ser utilizada como meio de prova, e fica ligado por dever de segredo relativamente àquilo de que tiver tomado conhecimento e não tiver interesse para a prova."

\section{Conclusão}

O segredo médico é um dos direitos fundamentais do paciente no direito português. Este direito deve ser complementado com o estudo do regime da protecção de dados pessoais, por um lado, e com a temática do direito de acesso ao processo clínico, por outro.

Pode-se afirmar que a lei portuguesa consagrou uma boa protecção do sigilo. Neste sentido recordemos apenas dois exemplos, a cobrança de honorários do médico depende de consulta prévia ao Bastonário e o testemunho do médico em tribunal apenas é obrigatório se ordenado por um tribunal. Por outro lado ainda, uma perspectiva como a Tarasoff doctrine está longe de reunir a unanimidade do pensamento jurídico e ético.

Mas como em tantas outras áreas do direito, da teoria à prática vai uma distância grande. E os casos de violação grosseira, diria mesmo boçal, do dever de sigilo, por parte de muitos profissionais de saúde é um facto lamentavelmente corrente... 
Resumo: 0 dever de sigilo do médico: um roteiro da lei portuguesa

0 Autor faz uma exposição das fontes internacionais e nacionais que protegem o direito ao sigilo médico, analisando os sujeitos obrigados à confidencialidade e o conteúdo do dever de sigilo. Na segunda parte enuncia as causas de justificação para a quebra do sigilo médico, em especial o consentimento, o consentimento presumido, o estado de necessidade e algumas autorizações especialmente previstas na lei. 0 texto pretende servir de guia prático para os profissionais do direito e da saúde nesta complexa matéria.

Palavras-chave: Sigilo médico; confidencialidade; causas de justificação; consentimento; autorizações legais de quebra do sigilo.

Summary: The physician's duty of confidentiality: a roadmap on Portuguese law The Author explains international and national sources of law of confidentiality in the physician-patient relationship and analyses the health-care and other professionals' duty of confidentiality. The second part of this article concerns the justification grounds for a legal breach of confidentiality, especially consent, presumed consent, necessity and some statutory authorizations. The text aims to serve as a practical guide for health care professionals in this complex area.

Key-words: Patient's privacy; doctor's confidentiality; justification clauses; consent; legal authorizations for breach of confidentiality.

Résumé: Le devoir de secret médical: un guide de la loi portugaise L'auteur expose les sources du droit international, européen et national du droit au secret médical et analyse les sujets qui ont le devoir de secret et le contenu de ce devoir. La deuxième partie de ce travail verse les faits justificatifs de la violation du secret médical, spécialement le consentement du patient, de consentement présumé, l'état de nécessité et certaines autorisations légales. Le texte a le but d'être un guide pratique pour les professionnels du droit et de la santé dans cette matière complexe.

Mots-clés: Secret médical; confidentialité; faits justificatifs; consentement; autorisations légales pour la violation du secret médical.

\section{Pedido de separatas:}

ANDRÉ GONÇALO DIAS PEREIRA

andreper@fd.uc.pt 